\title{
PEMURIDAN MELALUI PENDEKATAN KONSELING PASTORAL
}

\author{
Marthen Nainupu
}

Abstrak: Pemuridan adalah bagian yang tak terpisahkan dari keseluruhan pelayanan penggembalaan gereja. Pemuridan adalah suatu usaha sadar yang dilakukan oleh dan dari gereja secara terencana dan sistematis agar membantu setiap orang percaya atau anggota gereja dapat berakar kuat di dalam Kristus (Kolose 2:7), dan mencapai kedewasaan penuh serta tingkat pertumbuhan yang sesuai dengan kepenuhan Kristus (Efesus 4:13). Pemuridan sebagai suatu usaha sadar berlangsung dalam suatu proses yang lama dan panjang bahkan seumur hidup dengan tujuan akhir ialah agar seluruh warga jemaat dapat melatih dan memuridkan orang lain lagi. Proses pemuridan tersebut dapat dilakukan dengan berbagai pendekatan dan cara. Salah satu cara atau pendekatan yang disajikan dalam tulisan ini ialah melalui konseling pastoral. Konseling pastoral sebagai suatu pendekatan pemuridan dibangun di atas dasar atau pola pemuridan Tuhan Yesus. Pola pemuridan Tuhan Yesus telah memberikan inspirasi dan panduan yang mendasar bagi keseluruhan proses konseling pastoral pada umumnya, terutama dalam kaitannya dengan konseling pastoral sebagai suatu pendekatan pemuridan. Konseling pastoral sebagai suatu pendekatan pemuridan mengandung makna membangkitkan kesadaran kritis terhadap dosa, mewujudkan pemulihan, perubahan dan pertumbuhan rohani menuju kepada kedewasaan dalam Kristus. Makna lainnya ialah meneruskan karya pemuridan Tuhan Yesus sebagaimana Ia amanatkan kepada gereja sampai Ia datang kembali. Dengan adanya konseling pastoral sebagai suatu pendekatan pemuridan akan dapat memperkaya kehidupan gereja 
dengan berbagai pendekatan untuk meningkatkan pemuridan dan kerohanian warga jemaat.

Kata-kata kunci: Panggilan pemuridan, konseling pastoral.

Abstract: Discipleship is an integral part of church ministries. Discipleship is a conscious effort done by the church to help believers rooted in Christ (Colossians 2:7) and become mature according to the fullness of Christ (Ephesians 4:13). Discipleship takes time and the final purpose is to disciple another person. Discipleship process can be done by different approach and means. One of the means is through pastoral counseling. Jesus' Christ discipleship pattern gives the inspiration and pattern for pastoral counseling. Pastoral counseling helps raising awareness of sins, embodying recovery, changing and growing unto the fullness of Christ. Pastoral Counseling as the discipleship approach will enrich the church and raising congregation's spiritual life.

Keywords: Discipleship's invitation, counseling pastoral

\section{PENGANTAR}

Pemuridan adalah bagian yang tak terpisahkan dari keseluruhan pelayanan penggembalaan gereja. Pemuridan adalah suatu usaha sadar dari gereja yang dilakukan secara terencana dan sistematis agar setiap orang percaya atau anggota gereja dapat berakar kuat di dalam Kristus, (Kolose 2:7) mencapai kedewasaan penuh dan tingkat pertumbuhan yang sesuai dengan kepenuhan Kristus (Efesus 4:13). Sebutan murid yang dipakai di dalam kitabkitab Injil, khususnya Injil Matius, mengacu kepada kedua belas murid Tuhan Yesus, tetapi itu juga menunjuk kepada ketujuh puluh murid (Lukas 10:1) dan atau semua orang yang percaya dan mengikut Tuhan Yesus. Maka sebutan murid menunjuk kepada 
semua orang percaya atau pengikut Tuhan Yesus, baik pada masa lampau, saat ini, maupun di masa yang akan datang. ${ }^{1}$ Oleh karena itu, gereja (semua orang percaya masa kini) menyadari akan dirinya sebagai murid Tuhan Yesus yang mengemban tugas pemuridan. Sadar akan hal tersebut maka, sejak kehadiran gereja Ia sangat menaruh perhatian terhadap bagaimana mengupayakan agar warga gereja dapat berakar kuat dan mencapai kedewasaan penuh dalam kristus. Kehadiran dan keberadaan gereja di dunia ini adalah karena Tuhan Yesus sebagai Kepala Gereja. Oleh karena itu, gereja sangat sadar akan tugas dan fungsinya yaitu sebagai penerus dari misi Tuhan Yesus bagi kebaikan dan keselamatan umat manusia. Maka sejak kehadirannya, gereja tidak pernah berhenti berjuang untuk mewujudkan dirinya sebagai terang yang menuntun banyak orang kepada terang yang sesungguhnya. Konteks di mana gereja mewujudkan tugas dan fungsinya ialah dunia yang penuh dengan permasalahan, namun di dalamnya kebaikan-kebaikan Allah hendak dinyatakan (Yohanes 9:3). Dalam dunia seperti inilah gereja harus menghadirkan kabar baik dalam bentuk yang nyata melalui pelayanan karena gereja percaya bahwa ia terpanggil untuk menunaikan tugas dan fungsinya untuk kebaikan dan keselamatan manusia.

Dalam konteks teologi, semua bentuk pelayanan gereja mendapatkan fondasinya di atas dasar Tuhan Yesus sendiri. (1 Korintus 3:11). Ketika Tuhan Yesus datang ke dalam dunia, Ia sudah meletakkan dasar pelayanan itu melalui diri-Nya sendiri seperti yang dituliskan oleh Matius bahwa Ia berkeliling ke semua kota dan desa sambil mengajar di rumah-rumah ibadat memberitakan Injil kerajaan Allah dan melenyapkan segala penyakit dan kelemahan (Matius 9:35).

\footnotetext{
${ }^{1}$ R. T. France, Matthew Evangelist and Teacher (Grand Rapids, Michigan: Zondervan Publishing House, 1989), p. 261.
} 
Pada masa lampau, tugas dan fungsi gereja sering dipahami dan dimengerti secara terbatas pada "pemeliharaan jiwa-jiwa" (Cura Animarum). Namun pada saat ini, konsep tersebut telah disadari kurang memadai lagi dalam arti kehadiran gereja dan tugas pengutusannya. Pada masa kini tugas dan fungsi gereja lebih dimengerti sebagai kelanjutan dari karya penyelamatan Kristus. Maka apa yang dilaksanakan pada masa kini akan terus terarah kepada masa yang akan datang yakni kedatangan Kerajaan Allah.

Dari pemahaman teologis seperti yang dijelaskan sebelumnya, dapat teridentifikasi bahwa pengertian tugas dan fungsi gereja ialah keseluruhan aktifitas gereja yang berpusat pada satu titik sentral yaitu "hidup dan pelayanan Kristus." Maka seluruh aktifitas gereja ialah suatu usaha untuk menunjukan dan menjelaskan dalam bahasa kontemporer bahwa titik sentral tersebut dapat dipercayai dan setiap fungsi pelayanan selalu berkorespondensi dengan titik sentral tersebut. Titik sentral itu ialah "Kristus dan PelayananNya" untuk kita dan melalui kita. Pelayanan Kristus terwujud melalui kehadiran dan pelayanan gereja dan kehadiran seluruh tubuhnya. Semua jenis pelayanan yang berbeda-beda seperti liturgika, katekisasi, homiletika, konseling, dan lain-lain, harus tunduk dan berada di bawah kuasa Kristus. Apabila gereja kehilangan akar dan dasar pelayanan yang berpusat pada Kristus, hal tersebut akan menyebabkan kehilangan kekuatan dan terpecahpecahnya pelayanan itu sendiri yang pada akhirnya akan menimbulkan perpecahan dalam tubuh gereja itu sendiri.

Semua bentuk pelayanan yang dilakukan oleh gereja, bermula dari Tuhan Allah melalui Anak-Nya Yesus Kristus, Tuhan kita. Tuhan Yesus adalah dasar panggilan pelayanan gereja. Mengapa bukan iman yang menjadi dasar panggilan pelayanan gereja? Harus diakui bahwa iman bukanlah dasar panggilan pelayanan, sebab iman merupakan tanggapan, bangunan panggilan tersebut, 
sedangkan dasar, asal usul, prinsip, awal mula panggilan pelayanan ialah Tuhan Yesus sendiri. Ia yang berinisiatif memanggil manusia ciptaan-Nya itu untuk menjadi partner, rekan pelayanan, baik bagi Tuhan sendiri maupun bagi manusia dan dunia. Oleh kerena itu maka semua kegiatan pelayanan gereja bertolak dari prinsip-prinsip bahwa Tuhan Yesus adalah pemilik yang tertinggi dan yang empunya otoritas tertinggi dalam penggembalaan gereja. Pelayan sekaligus pemilik otoritas dalam gereja adalah Tuhan Yesus. ${ }^{2}$ Pemahaman yang benar terhadap pelayanan Tuhan Yesus, bahwa Ia adalah pemilik gereja akan sangat menentukan pengertian yang benar pula tentang pelayanan gereja, apakah itu pelayanan yang ditujukan kepada banyak orang atau kepada seorang individu dalam gereja. Mengetahui apa yang telah dilakukan dan akan terus dilanjutkannya terletak di dalam hati/pusat kehidupan gereja. Jadi Kristologi adalah titik sentral, pusat dari semua putaran dan aktifitas gereja. Gereja telah terpanggil untuk melakukan seperti yang sudah dilakukan dan dikerjakan oleh Tuhan Yesus. Semua bentuk pelayanan Tuhan Yesus seperti khotbah, mengajar dan menyembuhkan banyak orang adalah pelayanan "bela rasa" dan "belas kasihan" sebagai upaya untuk menghadirkan kerajaan Allah dalam kehidupan manusia secara nyata. Bentuk-bentuk pelayanan Tuhan Yesus sebagai usaha untuk menghadirkan keselamatan dari Allah Bapa-Nya secara riil dalam konteks kehidupan umat manusia. Semua kegiatan dan pelayanan Tuhan Yesus bertujuan untuk mengkomunikasikan Injil sebagai kabar baik yang merupakan suatu kebutuhan yang sangat penting, mendasar, dan mendesak bagi manusia.

Sadar akan tugas, fungsi, dan panggilannya, maka gereja terus mengembangkan berbagai cara dan metode untuk mencapai tujuannya, dan kalau kita perhatikan kehidupan gereja di era kita

\footnotetext{
${ }^{2}$ Paul Berneir, Ministry in the Church: A Historical and Pastoral Approach (Mystic, Connecticut: Twenty-Third Publications, 1992) p, 12.
} 
sekarang ini, di sana juga kita menemukan bahwa gereja terus mengembangkan berbagai metode atau cara untuk mengembangkan pertumbuhan gereja baik pertumbuhan kuantitatif maupun kualitatif. Berbagai cara itu pun dilakukan secara rutin misalnya melalui kegiatan-kegiatan tetap seperti khotbah, katekisasi, dan pembinaan iman sepanjang tahun maupun secara insidental yang dilakukan secara berkala seperti latihan penginjilan, seminar pertumbuhan gereja, program multiplikasi, dan lain-lain. Semuanya itu dilakukan semata-mata untuk mewujudkan cita-cita dan tujuan gereja yaitu menjadikan warga jemaat berakar kuat dalam Kristus dan menjadi terang bagi dunia yang menuntun banyak orang kepada kedewasaan penuh dalam Kristus dan pengenalan yang benar tentang Anak Allah.

Dalam tulisan ini, penulis ingin berpartisipasi dalam memikirkan dan mengembangkan suatu cara atau pendekatan bagaimana menolong warga jemaat untuk mencapai kedewasaan penuh dalam Kristus yang pada gilirannya dapat menjadi terang bagi dunia. Pendekatan yang akan diketengahkan dalam tulisan ini sebagai salah satu cara untuk lebih melengkapi anggota gereja berfungsi secara penuh sebagai terang bagi dunia. Pendekatan ini bukan satu-satunya dan bukan bermaksud untuk menggeser caracara yang telah dipakai gereja selama ini. Dengan pendekatan ini gereja akan semakin diperkaya dengan beragam cara untuk menolong dan memberdayakan warga gereja. Untuk itulah maka tulisan ini diberi judul "Pemuridan Melalui Pendekatan Konseling Pastoral".

Tema sebagaimana disebutkan di atas, berturut-turut akan dielaborasi sebagai berikut:

I. Pengantar. Bagian ini akan memberikan gambaran umum tentang tugas panggilan gereja.

II. Panggilan pemuridan. Bagian ini akan melihat asal usul 
panggilan dan maknanya serta membahas panggilan menjadi murid.

III. Proses menjadi murid. Bagian ini merupakan suatu usaha untuk melihat bagaimana proses pemuridan yang dilakukan oleh Tuhan Yesus.

IV. Pola Pemuridan Tuhan Yesus sebagai dasar Konseling Pastoral. Pada bagian ini merupakan suatu usaha untuk melihat apakah konseling pastoral memiliki hubungan yang kuat dengan pola pemuridan Tuhan Yesus. Apakah pola pemuridan yang dilakukan oleh Tuhan Yesus telah menjadi dasar yang memberi inspirasi bagi pengembangan konseling pastoral sebagai suatu pendekatan pemuridan.

V. Konseling pastoral sebagai suatu pendekatan pemuridan. Bagian ini akan membahas distingsi antara konseling sekuler dan konseling pastoral (kristen). Tujuan utama dari konseling pastoral. Makna konseling pastoral sebagai pendekatan pemuridan.

VI. Penutup dan kesimpulan.

\section{PANGGILAN PEMURIDAN}

\section{Panggilan Secara Umum}

Panggilan merupakan suatu kata yang tidak asing bagi kita bahkan kita gunakan setiap hari dalam pergaulan kita. Menurut Kamus Bahasa Indonesia, panggilan dapat diartikan sebagai suatu himbauan, ajakan, undangan, atau penyebutan nama sesuatu yang berkaitan dengan ajakan. ${ }^{3}$ Dalam bahasa Inggris, biasanya digunakan dua istilah yaitu "vocation" dan "calling". Kata "vocation" biasanya dipergunakan berkaitan dengan pekerjaan, jabatan, atau profesi yang lebih bersifat umum seperti dipahami

\footnotetext{
${ }^{3}$ W. S. J. Poerwadarminta, Kamus Umum Bahasa Indonesia (Jakarta: Balai Pustaka, 1984), hal 705.
} 
oleh Luther bahwa semua pekerjaan adalah panggilan (vokasi), sedangkan kata "calling" agak lebih bersifat khusus seperti memanggil nama seseorang atau sekelompok orang dengan tujuan tertentu, khususnya yang berkaitan dengan panggilan penyembahan, keselamatan, dan pelayanan. ${ }^{4}$ Tetapi sesungguhnya kedua kata tersebut mengandung arti yang hampir sama.

Sementara itu di dalam bahasa Latin dikenal istilah "vocare" yang dapat diartikan sebagai "memanggil, seruan, undangan, dan vocatio yang artinya panggilan". 5 Di dalam bahasa Yunani dipakai kata "kaleo" yang artinya memanggil, mengundang, berseru, memerintahkan, menyebut, atau menamai. ${ }^{6}$ Panggilan tersebut berkenaan dengan suatu tugas atau pekerjaan yang harus dikerjakan atau suatu tindakan yang harus diresponi dan ditindak lanjuti dalam bentuk aksi-aksi nyata.

Meskipun penulis sudah katakan bahwa panggilan adalah sebuah kata yang kita gunakan dalam keseharian kita, tetapi sesungguhnya kata panggilan mengandung makna "religius teologis". Panggilan adalah suatu ajaran atau doktrin di dalam Alkitab yang berkaitan dengan panggilan Allah kepada manusia untuk menjadi alat di tangan Tuhan, bagi kebaikan dan keselamatan manusia. Panggilan menunjuk kepada tindakan Allah atau Tuhan Yesus yang memanggil manusia untuk melakukan suatu tugas berkaitan dengan keselamatan manusia. Panggilan dalam pengertian ini lebih banyak kita temukan di dalam teologi Paulus. ${ }^{7}$ Panggilan berkaitan erat dengan bagaimana Allah memanggil manusia untuk menjadi partner-Nya dalam mewujudkan cita-cita

\footnotetext{
${ }^{4}$ Walter A. Elwell, Baker Theological Dictionary of Bible (Michigan: Baker Book's, 1996), pp. 80-81.

${ }^{5}$ K. Prent CM, J. Adisubrata dan W. J. S. Porwadarminta, Kamus Bahasa Latin-Indonesia (Yogyakarta: Kanisius 1969), hal. 936.

${ }^{6}$ George A. Buttrick, The Interpreter's Doctionary of the Bible, R-Z, vol. 4 (Nashville: Abingdon Press, 1962), p. 792.

${ }^{7}$ Ibid.
} 
keselamatan bagi seluruh manusia. Secara umum, panggilan Tuhan Yesus mengandung suatu misi, misalnya untuk mencari dombadomba yang hilang di antara orang Israel. "Pergilah kepada dombadomba yang hilang dari umat Israel" (Matius 10:6). Tetapi misi itu tidak berhenti di kalangan orang Israel saja melainkan terus meluas dan menjangkau kota-kota dan desa-desa di luar Israel. Tuhan Yesus menyeberang laut Galilea dan menjangkau kota-kota dan desa-desa di daerah Dekapolis, seberang Yordan.

Selain panggilan untuk mencari yang terhilang, di dalam panggilan yang sama juga terkandung misi pembebasan dari dosa melalui pengampunan. "Saudara-saudara, memang kamu telah dipanggil untuk merdeka" (Galatia 5:13). Sejak Tuhan Yesus hadir di rumah-rumah ibadah Ia terus mengumandangkan panggilan dan memproklamirkan Kerajaan Allah. Rumah-rumah ibadah atau sinagoge adalah pusat kehidupan rohani dan sekaligun pusat pendidikan. Tuhan Yesus tidak saja mengajar dengan kata-kata yang penuh kuasa, tetapi Ia menyatakannya pula dalam perbuatan dan tindakan nyata seperti memulihkan yang sakit. Pelayanan Tuhan Yesus adalah pelayanan pemulihan secara utuh, baik mengenai hal fisik, psikis, sosial, dan rohani.

\section{Panggilan Menjadi Murid}

Apabila kita memperhatikan catatan Injil Matius khususnya, maka di awal tulisannya, ia sudah menyatakan dengan jelas bahwa kedatangan Tuhan Yesus ke dunia ini adalah untuk menyelamatkan umat-Nya dari dosa mereka. "Ia akan melahirkan anak laki-laki dan engkau akan menamakan Dia Yesus, karena Dia-lah yang akan menyelamatkan umat-Nya dari dosa mereka" (Matius 1:21). Kemudian Tuhan Yesus mulai melaksanakan misi ilahi tersebut dengan berjalan berkeliling ke semua kota dan desa, seperti yang dilaporkan oleh Matius. "Demikianlah Yesus berkeliling ke semua 
kota dan desa; Ia mengajar dalam rumah-rumah ibadat dan memberitakan Injil Kerajaan Sorga serta melenyapkan segala penyakit dan kelemahan" (Matius 9:35). Panggilan menjadi murid berkaitan erat dengan maksud Tuhan Yesus yaitu Ia ingin mempersiapkan suatu generasi penerus. Ia mau melibatkan lebih banyak orang dalam misi tersebut, maka Ia mulai memanggil beberapa orang menjadi murid-Nya. (Matius 4 18-22) dan beberapa waktu kemudian Ia memanggil ke dua belas orang untuk menjadi murid-Nya (Matius 10: 1-4).

Dari laporan Matius, terlihat bahwa panggilan kepada kedua belas murid-Nya itu, tidak berlangsung serentak, tetapi terjadi dalam beberapa tahap (lihat Matius 4:18- 22; Matius 10: 1-4). Di samping itu panggilan Tuhan Yesus kepada kedua belas murid itu pun tidak terjadi dengan tiba-tiba. Menurut catatan Injil Yohanes, Yohanes Pembaptis sudah memperkenalkan Tuhan Yesus kepada banyak orang dan khususnya kepada dua orang muridnya (Yohanes 1:35-42). Andreas adalah murid Yohanes Pembaptis, namun setelah Yohanes Pembaptis memperkenalkan Tuhan Yesus kepada Andreas, dan ia sendiri bertemu dengan Tuhan Yesus, ia memutuskan untuk menjadi murid Tuhan Yesus. Jadi barangkali Tuhan Yesus sudah pernah bertemu dengan calon-calon muridNya beberapa kali sebelumnya. Menurut Bill Hull, ${ }^{8}$ setelah Tuhan Yesus memanggil keempat murid pertama (Markus 1:16-20), mereka sempat mengikut Tuhan Yesus dalam perjalanan singkat ke Kapernaum dan beberapa desa (Markus 1:21-39; Lukas 4:31-44). Tetapi setelah itu mereka meninggalkan Tuhan Yesus dan kembali kepada pekerjaan mereka semula yaitu sebagai penjala ikan (Lukas 5:1-11). Rupanya keempat murid tersebut masih pulang ke rumah mereka untuk beberapa urusan dan keperluan pribadi. Mereka baru mengambil keputusan akhir untuk menjadi murid Tuhan Yesus

\footnotetext{
${ }^{8}$ Bill Hull, Jesus Christ, Disciplemaker (Surabaya: Literatur Perkantas Jawa Timur, 2015), hal. 101. Lihat juga A. B. Bruce, The Training of the Twelve (Grand Rapids, Michigan: Kregel Publications, 1971), p. 11.
} 
penuh waktu setelah mereka mengalami kegagalan total dan tidak berhasil menangkap seekor ikan pun sepanjang malam (Lukas 5:111). Dalam Injil Lukas tercatat bahwa Tuhan Yesus naik ke perahu Simon dan mengajar orang banyak dari atas perahu itu. Di sini Simon Petrus tidak memberikan reaksi apa-apa, kalau Tuhan Yesus menaiki dan memakai perahunya untuk duduk dan mengajar dari atasnya, karena Simon sudah kenal Tuhan Yesus sebelumnya, bahkan pernah bersama Tuhan Yesus ke beberapa desa di Kapernaum. Pada perjumpaan inilah keempat murid itu menyerahkan diri secara penuh untuk menjadi murid Tuhan Yesus (Lukas 5:11).

Menurut A. B. Bruce, panggilan kepada kedua belas murid tersebut berlangsung dalam tiga tahap dan terdiri dari tiga kelompok, masing-masing kelompok terdiri dari empat orang. Kelompok pertama terdiri dari empat orang yaitu Simon Petrus, Andreas, Yakobus, dan Yohanes. Kelompok kedua terdiri dari empat orang yaitu Filipus, Bertholomeus atau Natanael, Thomas, dan Matius. Kelompok ketiga terdiri dari empat orang juga yaitu Yakobus anak Alfius, Thadeus atau Yudas anak Yakobus, Simon orang Zelot, dan Yudas Iskariot. ${ }^{9}$ Panggilan untuk menjadi murid memerlukan waktu dan pemikiran yang matang untuk membuat sebuah komitmen. Tuhan Yesus, Sang Guru, dengan sabar dan penuh kasih menantikan saat yang tepat untuk meyakinkan muridmurid bahwa di kemudian hari mereka adalah penerus dari misi ilahi yang sedang dikerjakan oleh Tuhan Yesus. Perhatikan bagian ini nanti ada kaitannya dengan konseling pemuridan, terkadang mereka yang menerima konseling tidak mudah membuat komitmen untuk berubah. Tetapi dengan semangat empati dan ketekunan seorang konselor, ia dapat menyakinkan mereka bahwa mereka pasti berhasil di kemudian hari. Inilah tahap awal panggilan

\footnotetext{
${ }^{9}$ A. B. Bruce, The Training of the Twelve (Grand Rapids, Michigan: Kregel Publications, 1971), p. 36.
} 
menjadi murid yang berlangsung cukup lama dan membutuhkan kesabaran dari seorang guru.

Pengembangan komunitas murid dan mempersiapkan suatu generasi penerus merupakan strategi perluasan Kerajaan Allah. Tuhan Yesus memanggil kedua belas murid untuk bergabung dengan Dia, mendengar dan melihat dari Dia apa yang Dia kerjakan, berbicara, dan belajar dari Tuhan Yesus. Para murid adalah agen-agen perluasan Kerajaan Allah. Kerajaan Allah tidak akan datang dan merasuk seluruh kehidupan manusia dengan mengadakan kebaktian kebangunan rohani sesaat, melainkan melalui suatu proses pemuridan, pengajaran, dan pendidikan yang terus menerus dan tetap. ${ }^{10}$ Hanya dengan cara demikian, orang percaya dapat mengalami pertumbuhan dan mencapai kedewasaan seperti yang diharapkan oleh Tuhan (Efesus 4:13-14) sebab di sanalah seorang belajar menjadi murid. Untuk menjadi seorang murid, maka pertama-tama ia harus mengidentifikasikan dirinya dan mau belajar dari sang Guru.

Panggilan menjadi murid lebih dari sekedar panggilan untuk beroleh keselamatan. Hari ini bangku-bangku gereja diisi dengan banyak orang yang selamat, tetapi mereka kurang berperan aktif untuk menjadi generasi penerus dari kabar baik. Mereka menjadi anggota "penggemar" ajaran Tuhan Yesus tetapi mereka bukan "pengikut" dan murid Tuhan Yesus. Hal semacam ini kita temukan pada zaman Tuhan Yesus, banyak orang senang dengan ajaran Tuhan Yesus tetapi mereka bukan pengikut Tuhan Yesus. Penggemar ajaran Tuhan Yesus, mereka hanya mengikut dari jauh, menolak untuk memikul tanggung jawab, dan tidak rela berkorban. Tetapi kalau mereka mendengar ajaran Tuhan Yesus atau melihat mujizat-mujizat yang dilakukan oleh Tuhan Yesus, mereka bertepuk tangan dan bersorak-sorak gembira. Akan tetapi ketika

${ }^{10}$ J. M. Price, Yesus Guru Agung (Bandung: LLB, tanpa tahun), hal. 53. 
mereka diminta untuk berkorban bersama Tuhan Yesus, mereka menghindar. Menjadi pengikut Yesus atau murid Tuhan Yesus adalah mereka yang mengikut dari dekat, mengambil bagian dalam pelayanan, dan rela berkorban. Panggilan menjadi murid mengandung suatu tantangan sebab ada harga yang harus dibayar. Panggilan menjadi murid harus berani mengambil keputusan untuk meninggalkan pekerjaan, keluarga, kesenangan untuk tinggal bersama dengan Tuhan Yesus, Sang Guru, belajar dari Tuhan Yesus, menerima ajaran Tuhan Yesus, berpikir seperti Tuhan Yesus, mengidentifikasikan diri dengan Tuhan Yesus, hidup seperti Tuhan Yesus, dan semuanya itu berlangsung dalam suatu persekutuan pribadi dengan Tuhan Yesus. Hal-hal semacam itu terlihat dengan sangat jelas dalam diri murid-murid Tuhan Yesus yang rela membayar harga.

Dari apa yang disampaikan tentang panggilan menjadi murid, penulis memahami bahwa panggilan Tuhan Yesus kepada manusia, pertama-tama adalah panggilan menjadi murid, bukan panggilan untuk bersaksi, melayani, ataupun keselamatan. Hal yang utama dari panggilan Tuhan Yesus ialah panggilan menjadi murid-Nya. Sebab hanya melalui panggilan menjadi murid, dan respon positif untuk menjadi murid, manusia akan memperoleh pencerahan, pemahaman, pengertian dan pengetahuan yang benar mengenai arti melayani, bersaksi dan keselamatan, dan dari situ pula lahirlah iman sebab "iman timbul dari pendengaran, dan pendengaran oleh firman Kristus" (Roma 10:17). Panggilan menjadi murid dalam konteks pemahaman Matius, tentu kita dapat pahami bahwa karena Matius berbicara kepada jemaat asal Yahudi yang secara umum mereka sudah mengetahui akan keselamatan melalui kepatuhan kepada Hukum Taurat, meskipun tidak seorang pun yang dapat mentaati hukum itu secara utuh. Tuhan Yesus hadir untuk memberi pencerahan dan mentransformasi pemahaman mereka mengenai keselamatan melalui iman kepada Tuhan Yesus dan hal itu dapat 
terbangun melalui komunitas murid. Maka panggilan menjadi murid adalah strategi Tuhan Yesus untuk melakukan transformasi pengetahuan rohani, pembaharuan kehidupan batiniah menuju kepada hidup kekal.

\section{PROSES MENJADI MURID}

\section{Murid Tinggal Bersama Tuhan Yesus}

Tahap pertama sudah dilalui dengan baik, di mana kedua belas murid sudah membuat komitmen untuk menjadi murid Tuhan Yesus. Mereka sudah meninggalkan perahu-perahu mereka, pekerjaan mereka, dan keluarga mereka. Sekarang mereka harus menjalani suatu proses panjang sebagai murid Tuhan Yesus. Untuk menjalani proses tersebut mereka harus tinggal bersama Tuhan Yesus, guru mereka. Ia berkata kepada mereka, "Marilah dan kamu akan melihatnya." Mereka pun datang dan melihat di mana Ia tinggal, dan hari itu mereka tinggal bersama-sama dengan Dia; waktu itu kira-kira pukul empat (Yohanes 1:39).

Bagaimana Tuhan Yesus membangun strategi pemuridan? Strategi pemuridan yang dibangun oleh Tuhan Yesus boleh dikatakan tidak berbeda dengan pemuridan para Rabi Yahudi pada zaman itu. Meskipun demikian ada hal-hal yang sangat berbeda dengan sistem pemuridan pada waktu itu. Para Rabi Yahudi mereka membuka sekolah dan calon murid harus mendaftar, artinya murid mencari guru. Para murid belajar di gedung sekolah. Para filsuf Yunani juga demikian, Sokrates misalnya, ia juga mempunyai murid yang datang kepadanya untuk belajar tentang kebaikan dan kebajikan. Hal yang membedakan strategi Tuhan Yesus dengan para guru zaman sebelumnya ialah bahwa Tuhan Yesus justru mencari murid dan memilih murid melalui doa semalam suntuk sebelum menetapkan mereka menjadi murid. "Pada waktu itu 
pergilah Yesus ke bukit untuk berdoa dan semalam-malaman Ia berdoa kepada Allah. Ketika hari siang, Ia memanggil muridmurid-Nya kepada-Nya, lalu memilih dari antara mereka dua belas orang" (Lukas 6:12-13). Para rabi mengajarkan banyak hal yang berguna untuk kepentingan murid sendiri. Tetapi Tuhan Yesus memanggil murid-murid untuk menjadi milik Kristus dan Kerajaan Allah, jadi output-nya adalah bertindak sesuai dengan tuntutan nilai-nilai kerajaan Allah.

Menjadi murid Yesus merupakan inisiatif dari Tuhan sendiri. Di saat manusia jatuh dalam dosa, Tuhan datang, mencari, dan memanggil mereka. Di saat Israel hidup dalam perbudakan di Mesir, Tuhan memanggil Musa untuk membebaskan mereka. Akhirnya Tuhan Yesus sendiri datang dan mencari manusia yang berdosa. Penulis Ibrani mengawali tulisannya dengan berkata, "Setelah pada zaman dahulu Allah berulang kali dan dalam pelbagai cara berbicara kepada nenek moyang kita dengan perantaraan nabi-nabi maka pada zaman akhir, ini Ia telah berbicara kepada kita dengan perantaraan Anak-Nya, yang telah Ia tetapkan sebagai yang berhak menerima segala yang ada. Oleh Dia, Allah telah menjadikan alam semesta. Dia menyatakan diri-Nya kepada manusia ( Ibrani 1:1, 2).

Tuhan Yesus mengambil inisiatif untuk memanggil para murid-murid dan kepada mereka Tuhan Yesus menyampaikan maksud-Nya. Sekolah pemuridan yang dilaporkan oleh penulis Injil Matius, banyak mengambil pola dari tradisi masyarakat Qumran di mana murid dilatih atau dipersiapkan untuk menjadi pemimpin. Sebuah model pemuridan untuk menjadi guru yang nantinya di kemudian hari mereka dapat memuridkan lagi orang lain. ${ }^{11}$ Para murid datang, mengikut, dan tinggal bersama-sama dengan Tuhan

\footnotetext{
${ }^{11}$ R. T. France, Matthew Evangelist and Teacher (Grand Rapids, Michigan: Zondervan Publishing House, 1989), p. 113.
} 
Yesus. Cara Tuhan Yesus melatih dan mendidik para murid tidak sama dengan para Rabi Yahudi maupun para filsuf Yunani. Tuhan Yesus yang masih sangat muda itu tampil beda. Tuhan Yesus tidak hanya sekedar mengajarkan kebenaran, tetapi Ia sendiri menjadikan diri-Nya kebenaran. Ia tidak sekedar mengajarkan hukum, tetapi ia sendiri menjadikan diri-Nya pelaku hukum. Tuhan Yesus menjadikan diri-Nya model bagi para murid-Nya. Tuhan Yesus tidak pernah menamatkan murid-murid-Nya seperti yang dilakukan oleh para Rabi Yahudi. Seorang murid Tuhan Yesus tetap dan terus sebagai murid, artinya mereka harus kembali dan memuridkan orang lain. ${ }^{12}$ Hal semacam itu terlihat ketika Tuhan Yesus mengutus murid-murid-Nya untuk menjadikan semua bangsa murid Tuhan, "Karena itu pergilah, jadikanlah semua bangsa murid-Ku, dan ajarlah mereka melakukan segala sesuatu yang telah Kuperintahkan kepadamu" (Matius 28:19- 20). Setelah para murid mengikuti dan menjadi murid Tuhan Yesus barulah kemudian mereka diutus untuk memuridkan orang lain.

Apabila para Rabi Yahudi dan filsuf Yunani mempunyai tempat belajar, tetapi Tuhan Yesus justru tidak menjadikan tempat, ruang-ruang kuliah sebagai pusat belajar. Tempat belajar Tuhan Yesus dan murid-murid-Nya ialah seluruh alam lingkungan kehidupan sebagai tempat belajar. "Dunia selalu menjadi ruang kelas bagi Tuhan Yesus dan para murid-Nya, sebab dunia menyediakan kesempatan untuk mengajarkan sesuatu pada setiap momen tertentu". ${ }^{13}$ Di pantai, di gunung, di bukit, di rumah tempat mereka singgah, di Bait Allah, di jalan-jalan atau pun di tengah laut. Dari pola ini kita bisa melihat bahwa Tuhan Yesus mau membuka mata para murid untuk melihat bahwa kehidupan ini sangat kaya dengan segala kebaikan Tuhan. Di mana saja dan

\footnotetext{
${ }^{12}$ Lloyd J. Ogilvie, gen. ed. The Communicator's Commentary: Matthew (Waco-Texas: Word Books, Publisher, 1982), p. 55.

${ }^{13}$ David Platt, Mengikut Yesus Tak Peduli Berapapun Harganya (Surabaya: Literatur Perkantas Jawa Timur, 2016), hal. 106.
} 
kapan saja kita dapat melihat dan menemukan rahmat dan keindahan Tuhan. Belajar mengenai kehidupan kita dapat peroleh di alam sekitar kita, sebab di sanalah Tuhan menaruh segala kebaikan-Nya, rahmat-Nya, dan berkat-berkat-Nya. Hal itu terlihat dengan sangat jelas dalam ajaran-ajaran dan perumpamaanperumpamaan Tuhan Yesus. Ia berbicara mengenai air, pohon, laut, bukit, bunga, dan seterusnya. Jauh sebelum Tuhan Yesus melihat alam sebagai sumber inspirasi pemuridan, atau media pengajaran, penulis Mazmur sudah mendengungkan hal tersebut. Pemazmur berkata, "Langit menceritakan kemuliaan Allah, dan cakrawala memberitakan pekerjaan tangan-Nya; hari meneruskan berita itu kepada hari, dan malam menyampaikan pengetahuan itu kepada malam. Tidak ada berita dan tidak ada kata, suara mereka tidak terdengar; tetapi gema mereka terpencar ke seluruh dunia, dan perkataan mereka sampai ke ujung bumi (Mazmur 19:2-5). Semua yang diajarkan oleh Tuhan Yesus, dapat diserap, dimengerti, dan dipahami dengan baik oleh para murid-Nya, hanya karena mereka rela meninggalkan semua kepentingannya dan mau tinggal serta hidup bersama dengan Tuhan Yesus. Belajar dekat dengan Tuhan Yesus, Sang Guru, dan Tuhan Tuhan Yesus selalu bersama-sama dengan murid-Nya, seperti yang disaksikan oleh Rasul Yohanes, "Apa yang telah ada sejak semula, yang telah kami dengar, yang telah kami lihat dengan mata kami, yang telah kami saksikan dan yang telah kami raba dengan tangan kami tentang Firman Hidup itulah yang kami tuliskan kepada kamu. Apa yang telah kami lihat dan yang telah kami dengar itu, kami beritakan kepada kamu juga, supaya kamu pun beroleh persekutuan dengan kami. Dan persekutuan kami adalah persekutuan dengan Bapa dan dengan Anak-Nya, Yesus Kristus" (I Yohanes 1:3). Tuhan Yesus selalu bersama-sama dengan murid-murid-Nya itulah pengalaman Yohanes seperti yang diungkapkan di atas. 


\section{Murid Menjadi Subyek dalam Proses Pemuridan}

Para Rabi Yahudi dan filsuf Yunani menjadikan murid sebagai obyek dalam proses belajar, mereka meneruskan sistem pendidikan tradisional. Sistem pendidikan tradisional memberi tekanan pada sang tokoh atau guru sebagai sumber ilmu. Sementara murid hanya berfungsi sebagai botol kosong yang siap diisi dengan berbagai pengetahuan dari sang guru. Sistem pendidikan tradisional itu, tentu memiliki keunggulannya tersendiri. Pengikut atau murid selalu berada dalam posisinya sebagai murid atau pengikut dengan semangat kepatuhan dan ketaatan tinggi kepada sang guru. Pembatinan sikap-sikap tersebut di atas secara terus menerus akan melahirkan suatu kebiasaan atau karakter yang sungguh amat baik dalam diri seorang murid. Nabi Yesaya misalnya meskipun ia telah menjadi seorang nabi besar pada zaman itu namun ia masih tetap memiliki sikap ketaatan seorang murid (Yesaya 50:4-5). Tampaknya Yohanes Pembaptis mewarisi dan meneruskan sistem pendidikan lama tersebut. Rasul Yohanes melaporkan bahwa Yohanes Pembaptis hanya meneruskan cara pendidikan lama, kurang memberi tekanan pada inovasi, apalagi transformasi. DalamYohanes 1:6-8 Yohanes Pembaptis hanya berperan sebagai pembawa kesaksian tentang terang itu. Ia bukan terang itu. Yohanes 1:23 lebih menegaskan lagi bahwa Yohanes Pembaptis hanyalah "suara". Matius menambahkan hal yang demikian bahwa Yohanes Pembaptis hanyalah "suara orang di padang belantara". Dari apa yang diamati oleh rasul Yohanes terhadap sikap mental Yohanes Pembaptis maupun pengakuannya sendiri, dapat dikatakan bahwa Yohanes Pembaptis hanya berperan sebagai alat, sarana, dan pesuruh bagi datangnya Sang Kristus. Sikap mental yang demikian dengan menempatkan diri sendiri sebagai murid, hamba, pelayan, alat, dan sarana tentunya ada hal-hal positif di dalamnya. Sikap-sikap positif itu misalnya kepatuhan, ketaatan, 
kerendahan hati, dan dengar-dengaran kepada Sang Guru sebagai wakil Tuhan.

Kelemahan dari sistem pemuridan tradisional, adalah sikap pandang murid terhadap diri sendiri hanya sejauh alat, sarana, corong, dan lain-lain. Hal tersebut bisa berdampak buruk terhadap sistem pemuridan. Misalnya murid menjadi pasif, kurang adanya sikap kritis, kreatif, dan inovatif. Secara psikologis hal tersebut juga dapat menjadi alasan untuk membenarkan dan mengembangkan sifat kemalasan. Istilah hamba bisa menjadi slogan yang kosong bahkan dapat menjadi alat/topeng untuk menyembunyikan nafsu kemalasan dengan selalu menunggu perintah dan arahan dari sang guru. Barangkali menyadari akan kelemahan dari sistem pemuridan tradisional itu, maka ketika Tuhan Yesus tampil di muka umum dengan pengajaranpengajaran-Nya ia memulai membangun suatu pola pendekatan baru. Tuhan Yesus mengamati dengan cermat keadaan waktu itu dan dari sana Ia mengetahui dengan pasti dan benar bahwa tantangan-tantangan baru tidak dapat diatasi dengan jawabanjawaban lama.

Oleh karena itu Tuhan Yesus sendiri membangun suatu strategi baru yang bergerak dari tesis "murid sebagai subyek". Inilah pola pendekatan yang dilakukan oleh Tuhan Yesus. Menurut laporan dari para murid Tuhan Yesus, kita dapat menemukan beberapa karakteristik yang ditampilkan oleh Tuhan Yesus dan itu semua menunjuk kepada suatu pola pemuridan yang bersifat transformatif. Rasul Yohanes mencatat bahwa Tuhan Yesus adalah terang dunia (Yohanes 8:12), tetapi Matius mencatat pula bahwa Tuhan Yesus menyapa murid-murid-Nya dengan sebutan "kamu adalah terang dunia" (Matius 5:14). Bagi Tuhan Yesus, murid-murid-Nya bukan sekedar obyek di mana Ia memindahkan informasi kepada mereka melainkan mereka adalah subyek dan agen dari transformasi 
pemuridan di kemudian hari. Murid-murid adalah subyek yang akan memuridkan orang lain setelah tiga tahun. Ini adalah suatu pendekatan baru yang sedang ditampilkan oleh Tuhan Yesus. Dalam model pendidikan lama, guru sebagai pusat. Dalam model pemuridan Tuhan Yesus, gaya berpikir guru dan murid adalah sama-sama subyek pembelajaran.

Dalam Yohanes 15:14, Tuhan Yesus menyapa murid-muridNya dengan sebutan sahabat-Ku. Cara Tuhan Yesus memperlakukan para murid bukan sebagai obyek tetapi Ia mengangkat mereka setara dengan Dia. Dalam sebutan sahabat menunjukkan ada kesetaraan, kemitraan, kerekanan, kawan kerja, dan seterusnya. Kesetaraan/ketemanan menurut Yohanes ialah bahwa Tuhan Yesus menaikkan, dan mendudukan para murid-Nya satu meja dengan Dia. Hal ini berbeda dengan apa yang dikatakan Paulus dalam Filipi 2:6-8, di mana Tuhan Yesus yang menurunkan dirinya setara/sama dengan manusia. Tetapi dalam Yohanes 15:14, Tuhan Yesus tetap sebagai sang guru dan Tuhan yang menarik, "meninggikan" murid-murid-Nya setara dengan Dia. Inilah model pemuridan yang telah dilakukan oleh Tuhan Yesus. Murid bukanlah obyek melainkan subyek dalam proses pemuridan dan pelaku pemuridan di masa yang akan datang. Tuhan Yesus melihat dan menjadikan para murid-Nya sebagai subyek dalam proses belajar. Tuhan Yesus menjadikan para murid sebagai mereka yang sudah dilengkapi dengan segala kemampuan dan potensi dari Tuhan, dan fungsi guru hanya sebagai motivator yang mendorong murid untuk mengembangkan potensi dirinya. Pola ini menjadikan murid sangat aktif dan kreatif sebagai subyek yang mengatur dirinya secara bertanggung jawab.

Salah satu indikator dari keterlibatan para murid sebagai subyek ialah Tuhan Yesus mau mendengarkan mereka. Dalam kebersamaan Tuhan Yesus dengan para murid, tidak jarang Tuhan 
Yesus bertanya kepada mereka. Dengan bertanya, berarti Tuhan Yesus mau mendengarkan dari mereka, apa yang menjadi kebutuhan mereka, bagaimana pemahaman mereka, apa harapan mereka, dan apa yang menjadi kebutuhan mereka. Oleh karena para murid sebagai subyek, maka Tuhan Yesus mencurahkan seluruh perhatian-Nya kepada mereka. Tuhan Yesus mendengarkan dengan sungguh-sungguh. Mendengarkan bukanlah suatu kegiatan pasif, mendengar dengan pura-pura. Tidak. Tuhan Yesus selalu mendengarkan secara aktif kepada murid-murid-Nya. ${ }^{14}$ Ketika Tuhan Yesus di dunia ini, Ia selalu bertanya kepada mereka yang menanggung beban berat demikian, "Maukah engkau sembuh?" (Yohanes 5:6), “Apa yang kau kehendaki supaya Aku perbuat padamu?" (Lukas 18:41), Tuhan Yesus berbicara langsung kepada "hati" kepada mereka yang berdiri di hadapan-Nya. Tuhan Yesus sangat tergerak hati-Nya oleh belas kasihan terhadap mereka yang terlantar (Matius 9:36). Mendengarkan adalah jiwa dan semangat Tuhan Yesus dalam memahami para murid sebagai subyek yang akan meneruskan tugas pemuridan tersebut di kemudian hari.

Pada saat murid-murid tinggal bersama dengan Tuhan Yesus, maka di sana juga terjadi percakapan dan keakraban di antara guru dan murid. Tuhan Yesus sangat memberi perhatian kepada percakapan dan hubungan secara personal. Banyak waktunya Ia habiskan dengan bercakap-cakap dengan murid-murid-Nya. Di tengah-tengah pelayanan-Nya kepada orang banyak, Ia selalu mencari kesempatan untuk berbicara dengan para murid. Dalam dialog dan keakraban ini terjadilah proses saling mengenal, terutama para murid mengenal siapa guru mereka. Perlakuan Tuhan Yesus terhadap para murid-Nya dengan menjadikan mereka sebagai subyek didasarkan pada relasi-Nya dengan Bapa-Nya

\footnotetext{
${ }^{14}$ Ann Armstrong, Listening for the Healing Word (Grandview-USA: Desert Stream Press, 2009), p. 31.
} 
(Yohanes 15:9). Relasi semacam ini adalah relasi sejati, relasi pribadi dengan pribadi.

Untuk mengenal Tuhan Yesus dengan baik maka perlu percakapan dan keakraban. Bergaul dengan Tuhan, bersekutu dengan Tuhan dan ini merupakan kelanjutan dari suatu perjumpaan secara pribadi, dialog dan keakraban terjalin di saat tinggal bersama-sama. Selain itu terjadi pula saling mempercayai, artinya murid-murid menaruh percaya dan harapannya kepada Tuhan Yesus dan pada saat yang sama Tuhan Yesus mempercayakan tugas pemuridan selanjutnya kepada para murid. Di samping itu juga terjadi saling berkomitmen untuk bekerjasama. Tuhan berjanji akan senantiasa menyertai mereka dalam tugas pemuridan dan para murid juga menyatakan komitmennya untuk melaksanakan tugas pemuridan tersebut dengan setia, dan sungguh-sungguh bergantung hanya kepada kekuatan Tuhan. Dari perjumpaan, dialog dan keakraban murid-murid membangun pengalaman bersama Tuhan Yesus dan Ia sangat menghargai potensi para murid dan karena itu ia mendorong mereka untuk terus mengembangkan semua potensi dirinya.

Sebelum muncul teori-teori dan penelitian modern tentang pengaruh lingkungan, ternyata bahwa di Israel pada zaman dulu sudah mengenal dan mempraktekkannya. Dalam Kitab Amsal, Salomo berkata "Siapa bergaul dengan orang bijak menjadi bijak, tetapi siapa berteman dengan orang bebal menjadi malang" (Amsal 13:20). Tampaknya ungkapan Salomo tersebut merupakan ekspresi pengalaman dari para leluhur Israel, di mana Musa mempengaruhi Yosua, Elia mempengaruhi Elisa, dan lain-lain. Tuhan Yesus hadir di tengah dunia, memanggil murid-murid kepada-Nya dan memberikan pengaruh-pengaruh rohani kepada mereka. Tidak jarang Tuhan Yesus berbicara kepada banyak orang, Ia berbicara secara khusus untuk para murid dan tidak jarang pula Ia berbicara 
hanya dengan seorang, misalnya dengan Nikodemus, wanita Samaria, orang yang sakit di Kolam Betesda, dan lain-lain. Pola semacam ini kemudian diteruskan oleh rasul Paulus dalam proses mempersiapkan generasi penerus. Paulus memberi pengaruhpengaruh rohani kepada Timotius, Titus, dan mungkin beberapa murid lainnya seperti Sopater, Aristarkus, Sekundus, Gayus dan lain-lain.

\section{Materi Pemuridan}

Tuhan Yesus mengajarkan berbagai hal yang mendasar yang berhubungan dengan pertanyaan-pertanyaan besar, mendalam dan menyeluruh tentang manusia, dunia, dan Tuhan. Begitu luasnya cakupan ajaran Tuhan Yesus dan hal tersebut diakui sendiri oleh Yohanes salah seorang murid-Nya bahwa, "Masih banyak hal-hal lain lagi yang diperbuat oleh Yesus, tetapi jikalau semuanya itu harus dituliskan satu per satu, maka agaknya dunia ini tidak dapat memuat semua kitab yang harus ditulis itu" (Yohanes 21:25). Untuk kepentingan tulisan ini, penulis mencoba untuk memikirkan beberapa pokok materi pemuridan Tuhan Yesus.

\section{Pengembangan Pembentukan Karakter Spiritual}

Di dalam catatan-catatan kitab Injil, tidak jarang kita menemukan bahwa Tuhan Yesus mengajar di rumah-rumah ibadat. Para penulis Injil menggunakan kata "mengajar" yang secara spesifik menunjuk kepada aktivitas seorang guru. Aktivitas Tuhan Yesus sebagai seorang guru tidak sama dengan kegiatan pemuridan dari para Rabi Yahudi. Matius mencatat kesan pendengar-Nya sebagai berikut, "Dan setelah Yesus mengakhiri perkataan ini, takjublah orang banyak itu mendengar pengajaran-Nya, sebab Ia mengajar mereka sebagai orang yang berkuasa, tidak seperti ahliahli Taurat mereka" (Matius 7:28-29). Para Rabi Yahudi 
mengajarkan hukum Taurat tetapi mereka sendiri tidak terikat oleh hukum ajaran mereka. "Ahli-ahli Taurat dan orang-orang Farisi telah menduduki kursi Musa. Sebab itu turutilah dan lakukanlah segala sesuatu yang mereka ajarkan kepadamu, tetapi janganlah kamu turuti perbuatan-perbuatan mereka, karena mereka mengajarkannya tetapi tidak melakukannya. Mereka mengikat beban-beban berat, lalu meletakkannya di atas bahu orang, tetapi mereka sendiri tidak mau menyentuhnya" (Matius 23:2-4). Para Rabi Yahudi membina karakter murid dengan berbagai macam aturan yang sangat rinci yang sangat mengikat dan membebani murid. Pembentukan karakter dengan aturan dan larangan kepada murid hanya akan memberi perhatian kepada aspek tampilan luarnya saja, sementara aspek batiniah yang merupakan pusat kehidupan karakter belum tersentuh sama sekali.

Pembentukan karakter yang dibangun oleh Tuhan Yesus justru kebalikan dari pada para rabi. Tuhan Yesus mengajar dengan penuh kuasa dan kuasa itu terletak di dalam diri Tuhan Yesus, di mana "Ia mewujudkan kebenaran dalam hidup-Nya, bahkan Ia sendiri adalah kebenaran". ${ }^{15}$ Kepribadian dan karakter spiritual rohani-Nya mempunyai daya lekat tersendiri bagi para pendengar dan muridmurid-Nya. Ketika Tuhan Yesus mengajar, Ia tidak saja mentransfer pengetahuan tetapi Ia mentransfer kehidupan-Nya. Tuhan Yesus sedang membangun karakter spiritual ${ }^{16}$ artinya aspek batiniah menjadi perhatian utama, bukan yang tampilannya. Tuhan Yesus menjadikan Diri-Nya sendiri sebagai teladan atau model dalam pemuridan, Ia tidak hanya mengajar dengan kata-kata saja tetapi dengan tindakan nyata yang mengalir dari kedalaman cintanya kepada para murid.

\footnotetext{
${ }^{15}$ J. M. Price, Yesus Guru Agung (Bandung: Lembaga Literatur Baptis, tanpa tahun), hal. 5.

${ }^{16}$ William R. Yount \& Mike Barnett, Called To Reach (Nashville, Tennessee, B \& H Publishing Group, 2007), p. 15.
} 
Mengapa pengembangan pembentukan karakter spiritual? Kalau Tuhan Yesus mengajar di rumah ibadat itu berarti pendengar dan murid-murid adalah orang-orang yang sudah mengetahui kebenaran. Sebagian besar pendengar-Nya adalah orang-orang beragama, baik dari kalangan Yahudi maupun penganut agama Yahudi. Rumah-rumah ibadat adalah tempat berkumpul semua orang beragama, yang sudah tentu paham tentang kebenaran dan apa yang baik. Tetapi permasalahannya ialah mengetahui kebenaran, itu tidak secara otomatis melakukannya. Inti persoalannya yaitu perwujudan pengetahuan tentang kebenaran dalam aksi nyata. Di sanalah Tuhan Yesus mengajar, baik kepada banyak orang maupun kepada para murid-Nya tentang pentingnya perwujudan karakter spiritual. Karakter spiritual tampak dengan sangat jelas dalam dua hal yaitu Firman dan doa. Sebelum Tuhan Yesus melaksanakan tugas penebusan-Nya, Ia berpuasa dan berdoa. Ketika Tuhan Yesus menghadapi godaan dan serangan iblis, Ia mengingat akan Firman. Sebelum Tuhan Yesus memilih para murid Ia ingat pentingnya berdoa. Dengan singkat dapat dikatakan bahwa karakter spiritual tercipta melalui relasi dan dialog yang bermakna dengan Tuhan melalui Firman dan doa. Melalui Firman dan doa akan dapat terbangun pola berpikir, terbentuk cara menilai dan pola bertindak (2 Timotius 3:16). Membangun karakter spiritual berarti berpikir sebagaimana Allah berpikir, menilai seperti Tuhan menilai dan bertindak sebagaimana yang Tuhan lakukan. ${ }^{17}$ Membentuk karakter spiritual seperti itulah yang Tuhan Yesus tularkan kepada para murid-Nya, Ia memuridkan mereka melalui keteladanan karakter spiritual yang terbangun dan di dalam diri-Nya. Relasi yang bermakna dengan Tuhan adalah suatu relasi personal. Melalui itu semua, Tuhan Yesus mau menanamkan dan mengajarkan kepada para murid-Nya, betapa pentingnya dimensi batiniah kehidupan seorang murid.

\footnotetext{
${ }^{17}$ William R. Yount \& Mike Barnett, Called To Reach, p. 25.
} 
Sebab dari dalam hati seseorang muncul segala kejahatan bukan tampilan luarnya.

\section{Pengembangan Pembentukan Karakter Alkitabiah}

Di bagian akhir dari khotbah Tuhan Yesus di bukit, Ia menantang para pendengar dan para murid-Nya untuk mengambil keputusan secara bijak. Untuk maksud tersebut Tuhan Yesus memberikan sebuah perumpamaan tentang "dua macam dasar" (Matius 7:24-27). Inti perumpamaan itu ialah "mendengarkan dan melakukan sama dengan bijaksana, mendengarkan dan tidak melakukan sama dengan bodoh". Berkaitan dengan pengembangan pembentukan karakter Alkitabiah, dapat dikatakan bahwa Tuhan Yesus mau menolong para pendengar dan para murid untuk membangun karakter kepatuhan dan keyakinan terhadap otoritas Firman Tuhan. Alkitab atau Firman Tuhan menyatakan dan menghadirkan kebenaran-kebenaran final, kebenaran kekekalan. Alkitab memiliki otoritas dan mempunyai daya pengaruh yang sangat besar terhadap kehidupan karakter para murid. Alkitab merupakan panduan bagi murid untuk dapat mengenal siapa dirinya sebagai seorang murid, bagaimana hubungannya dengan Tuhan, apa yang Tuhan kehendaki untuk dilakukan. ${ }^{18}$

Dengan memahami maksud Allah sebagaimana yang tertulis di dalam Alkitab, maka di sana pula akan terbentuk nilai-nilai agama, moral, dan nilai rohani yang sejalan dengan amanat firman, di sana juga terbangun perilaku Alkitabiah. Dalam kebersamaan Tuhan Yesus dengan para murid-Nya, Ia sangat memberi perhatian kepada mereka dengan membentuk perilaku Alkitabiah. Tuhan Yesus berulang kali memperingatkan mereka tentang perasaan sombong atau tinggi hati, ketamakan, amarah, hawa nafsu, dan perasaan buruk lainnya. Tuhan Yesus meminta para murid agar mereka

\footnotetext{
${ }^{18}$ William R. Yount \& Mike Barnett, Called To Reach, p. 39.
} 
"sempurna, sama seperti Bapamu yang di sorga adalah sempurna" (Matius 5: 48). Kehidupan karakter para murid berkaitan erat dengan kuasa Firman dalam Alkitab. Apabila pengembangan pembentukan karakter spiritual memberi perhatian pada relasi personal, maka pada bagian pembentukan karakter Alkitabiah lebih memberi tekanannya pada kesadaran dan keyakinan, kepatuhan dan ketaatan akan kuasa Firman yang tertulis yaitu Alkitab. Pengembangan karakter Alkitabiah dimaksudkan untuk membentuk konsep-konsep Alkitabiah yang sejalan dengan maksud baik dari Tuhan. Para murid dibekali dengan konsep-konsep yang benar, oleh karena merekalah yang akan menyampaikan isi hati Allah kepada manusia di kemudian hari. Oleh sebab itu mereka harus tahu dan memahami dengan benar bentuk konsep-konsep Alkitabiah di dalam memuridkan orang lain di kemudian hari.

\section{Pengembangan Pembentukan Karakter "Bela Rasa" (Compassionate)}

Ketika Tuhan Yesus berkeliling ke semua kota dan desa, hatiNya sangat terharu ketika ia melihat orang banyak. Matius mencatat, "Melihat orang banyak itu, tergeraklah hati Yesus oleh belas kasihan kepada mereka, karena mereka lelah dan terlantar seperti domba yang tidak bergembala (Matius 9:36). Tuhan Yesus tidak melihat hanya sebatas orang banyak, tetapi Ia melihat sampai kepada kebutuhan mereka yang terdalam dan personal. Mereka membutuhkan akan kehadiran orang lain bagi mereka, tetapi mereka tidak mendapatkannya dari para rabi mereka (Yehezkiel 34:5-8). Tergerak hati-Nya oleh belas kasihan adalah karakter dan sifat Tuhan Yesus. Pelayanan Tuhan Yesus selama kurang lebih tiga tahun, para murid-Nya melaporkan bahwa Ia menghabiskan waktu-Nya untuk berbagi rasa dengan orang banyak. Para penulis kitab Injil mencatat kata "tergerak hati-Nya oleh belas kasihan" 
berulang kali. Maka Tuhan Yesus sendiri berkata, "yang Kukehendaki ialah belas kasihan" (Matius 9:13).

Belas kasihan (compassion) berasal dari bahasa latin "Compati". Kata tersebut terdiri dari dua kata yaitu "Com" artinya "dengan" dan "Pati" artinya "memikul atau menderita". Jadi ide dasar dari kata belas kasihan ialah memikul, menderita dengan orang lain. ${ }^{19}$ Sifat dan karakter inilah yang ditampilkan oleh Tuhan Yesus. Ketika Tuhan Yesus di dunia ini, Ia selalu bertanya kepada mereka yang menanggung beban berat demikian: (Yohanes 5:6) "Maukah engkau sembuh?", (Lukas 18:41) “Apa yang kau kehendaki supaya Aku perbuat padamu?”, (Matius 9:36) Tuhan Yesus berbicara langsung kepada kedalaman hati dan kebutuhan mereka yang berdiri di hadapan-Nya. Tuhan Yesus sangat tergerak hati-Nya oleh belas kasihan terhadap mereka yang terlantar.

Dalam kaitan dengan pengembangan pembentukan karakter bela rasa, penulis teringat akan kisah Tuhan Yesus memberi makan lima ribu orang. Menurut catatan Injil Yohanes, Tuhan Yesus bertanya kepada para murid-Nya, "Di manakah kita akan membeli roti, supaya mereka ini dapat makan?" (Yohanes 6:5). Melalui pertanyaan ini Tuhan Yesus ingin membangkitkan rasa belas kasihan kepada orang lain. Tuhan Yesus melatih kepekaan muridmurid untuk melihat dan merasakan kesulitan orang lain. Sekaligus ingin mengetahui sejauh mana kepekaan terhadap kebutuhan dan kesulitan orang lain. Meskipun jawaban para murid mengecewakan, tetapi hal itu tidak pernah menyurutkan semangat Tuhan Yesus untuk terus mendorong dan membangkitkan kepekaan dan bela rasa terhadap orang lain. Maka di akhir dari suatu proses pemuridan yang lama dan panjang, kita menemukan bahwa di dalam tulisan Rasul Yohanes maupun Rasul Petrus sangat

\footnotetext{
${ }^{19}$ William R. Yount \& Mike Barnett, Called To Reach, p. 109.
} 
berbeda dengan ketika pada awal mereka menjadi murid Tuhan Yesus.

\section{Menjadi Murid}

Setelah Tuhan Yesus mendampingi para murid selama kurang lebih tiga setengah tahun, kini mereka sudah dapat siap menjadi seorang murid yang bertugas untuk memuridkan orang lain. Maka di bagian akhir inilah para murid diutus untuk melaksanakan tugas pemuridan. Perintah untuk memuridkan orang lain kita temukan di dalam Injil Matius 28:19, "Karena itu pergilah, jadikanlah semua bangsa murid-Ku”. Memang di tengah-tengah masa pemuridan, Tuhan Yesus menyuruh mereka untuk melakukan tugas pelayanan. Mereka diutus berdua-dua untuk melakukan tugas membebaskan orang lain dari berbagai hambatan kehidupan (Markus 6:6 ${ }^{\mathrm{b}}-12$ ). Tetapi tugas pemuridan tersebut baru mengalami ketuntasannya setelah Tuhan Yesus meninggalkan mereka. Kalau gereja masih ada sampai hari ini, itu merupakan kepatuhan para murid untuk memuridkan orang lain. Tugas pemuridan seperti inilah yang sekarang diteruskan oleh gereja Tuhan masa kini. Gereja sebagai penerus dari tugas pemuridan, ia telah dan sedang serta akan terus melakukan tugas tersebut melalui berbagai cara dan pendekatan, sampai Tuhan Yesus datang kembali.

\section{POLA PEMURIDAN YESUS: DASAR KONSELING PASTORAL}

Melihat dari panggilan pemuridan yang telah dilakukan oleh Tuhan Yesus, dan dari keseluruhan proses pemuridan, di sana tergambar dengan jelas bahwa pola-pola pemuridan yang dilakukan oleh Tuhan Yesus telah menjadi dasar yang kuat dan dapat memberi inspirasi yang signifikan untuk dapat mengembangkan konseling pastoral sebagai suatu pendekatan pemuridan. Berikut ini 
akan disampaikan beberapa hal yang disarikan dari keseluruhan proses pemuridan sebagaimana sudah digambarkan sebelumnya.

\section{Orientasi pada Tujuan}

Penulis Injil Matius mencatat bahwa kedatangan Tuhan Yesus adalah untuk memulihkan hubungan antara manusia dengan Allah. "Ia akan melahirkan anak laki-laki dan engkau akan menamakan Dia Yesus, karena Dialah yang akan menyelamatkan umat-Nya dari dosa mereka" (Matius 1:21). Di sini terlihat dengan sangat jelas bahwa adapun tujuan kedatangan Tuhan Yesus adalah untuk menuntun dan menghubungkan kembali manusia ke dalam persekutuan dengan Allah melalui pengorbanan Kristus. Ia telah datang untuk memulihkan hubungan yang telah rusak antara manusia dengan Tuhan dengan jalan mendamaikan manusia dengan Allah, oleh kematian-Nya (Roma 5:10). Orientasi pada tujuan telah memberi dasar kuat bagi tujuan konseling pastoral. Hal mana nantinya akan terlihat di dalam tujuan-tujuan konseling pastoral misalnya memulihkan hubungan antar warga jemaat dalam persekutuan Kristen dan dalam persekutuannya dengan Tuhan, agar mereka dapat bertumbuh dan mencapai kedewasaan penuh dalam Kristus. $^{20}$

\section{Orientasi Pada Kebutuhan}

Selain orientasi pada tujuan keselamatan, Tuhan Yesus juga sangat menaruh perhatian terhadap kebutuhan tiap-tiap murid-Nya secara pribadi. Kebutuhan setiap murid merupakan suatu hal yang sangat penting yang dilihat oleh Tuhan Yesus dalam pemuridan. Pendekatan Tuhan Yesus terhadap kebutuhan setiap murid juga tidak dilakukan dengan cara yang sama pada setiap murid. H. Norman Wright yang mengutip dari Gary Collins yang mengatakan

\footnotetext{
${ }^{20}$ Seward Hiltner, Pastoral Counseling (Nashville: Abongdon Press, 1949), p. 19.
} 
bahwa, "Tuhan Yesus tidak hanya menghadapi orang-orang dengan cara yang berbeda-beda, tetapi Dia juga berhubungan dengan pribadi-pribadi pada tingkat kedalaman dan tingkat keakraban yang berbeda". ${ }^{21}$ Hal ini dilakukan oleh Tuhan Yesus berkenaan dengan tingkat kepedulian-Nya terhadap kebutuhan yang terdalam dari setiap murid-Nya. Kepedulian terhadap kebutuhan telah memberikan dasar bagi pendekatan konseling pastoral.

\section{Orientasi pada Pribadi atau Murid Menjadi Subyek}

Menghargai dan menerima sesama sebagai subyek adalah bentuk dan ciri khas dari pola pemuridan Tuhan Yesus. Kita tahu bahwa para murid dengan latar belakang dan sifat serta karakter yang berbeda-beda. Petrus murid yang emosional, bersifat impulsif; Yohanes yang pemarah; Simon orang Zelot yang radikal, ${ }^{22}$ tetapi Tuhan Yesus tetap menerima mereka sebagaimana adanya, sebagai pribadi-pribadi yang unik. Tuhan Yesus menerima dan mengakui mereka sebagai pribadi dengan segala kekuatan dan kelemahannya dan Ia melibatkan mereka sebagai subyek dalam proses pemuridan. Tuhan Yesus tidak hanya mengetahui kelemahan mereka tetapi Ia juga melihat kekuatan dan potensi mereka. Hal ini telah menjadi dasar dan sumber inspirasi untuk konseling pastoral yang akan tampak dalam proses konseling pastoral.

\section{Orientasi Pada Pengembangan Pembangunan Karakter Rohani}

Inti dari keseluruhan proses pemuridan Tuhan Yesus adalah membentuk karakter rohani yang sesuai dengan Firman Tuhan. Peletakan dasar pembentukan karakter oleh Tuhan Yesus juga

\footnotetext{
${ }^{21}$ H. Norman Wright, Konseling Krisis, Membangun Orang Dalam Krisis dan Stres (Malang: Gandum Mas, 1993), hal. 36.

22 J. M. Price, Yesus Guru Agung, hal. 22-23.
} 
merupakan salah satu pilar dari pengembangan konseling pastoral. Kalau penulis mau sederhanakan konseling pastoral, maka hanya ada satu kalimat pendek yaitu "membongkar manusia lama" dan "membangun manusia baru" menuju integritas dalam Kristus. Membongkar manusia lama adalah satu syarat penting bagi pemuridan guna terbangunnya kehidupan manusia baru. Mengapa penting? Karena kita semua tahu bahwa semua orang telah jatuh ke dalam dosa dan secara alami hidup kita berpusat pada diri sendiri, percaya pada diri sendiri, bersandar pada kekuatan dan sumber daya sendiri. ${ }^{23}$ Singkatnya manusia itu telah mengeliminasi Tuhan dari hidupnya. Maka manusia lama harus dihancurkan, dibongkar, atau dimatikan seperti yang dimaksudkan oleh rasul Paulus. "Karena itu matikanlah dalam dirimu segala sesuatu yang duniawi, yaitu percabulan, kenajisan, hawa nafsu, nafsu jahat dan juga keserakahan, yang sama dengan penyembahan berhala, semuanya itu mendatangkan murka Allah atas orang-orang durhaka (Kolose 3:5-6). Setelah manusia lama dibongkar barulah dapat terbangun atau muncul manusia baru. Dalam kaitan dengan pemuridan, maka membongkar karakter yang merusak, merupakan tugas utama dari sebuah proses pemuridan. Konseling pastoral mempunyai peran sangat jelas dalam hal memperbaiki perilaku yang merusakan dan membangun perilaku yang efektif konstruktif.

\section{Membangun Karakter Bela Rasa}

Karakter ini adalah suatu kekuatan batiniah yang mampu mendorong seseorang untuk peduli terhadap orang lain. Jika para murid dipersiapkan untuk memuridkan orang lain, maka karakter bela rasa merupakan kata kunci untuk maksud tersebut. Mencintai orang lain atau mengasihi kemanusiaan manusia berawal dari karakter bela rasa. Oleh karena itu maka karakter tersebut telah

\footnotetext{
${ }^{23}$ Neil T. Anderson, Menjadi Gereja Pembuat Murid (Yogyakarta: Yayasan Gloria, 2016), hal. 30.
} 
dibangun oleh Tuhan Yesus dengan para murid-Nya. Ia memotivasi dan membangkitkan rasa kecintaan terhadap orang lain. Seorang konselor pastoral hendaknya memiliki karakter seperti Tuhan Yesus yang selalu berbelas kasihan kepada mereka yang tersisih dan terabaikan.

Dari beberapa hal yang disebutkan di atas, terlihat bahwa Tuhan Yesus adalah contoh terbaik konselor yang menakjubkan dengan kepribadian, pengetahuan, dan keahlian-Nya, Ia dapat membantu siapa saja yang membutuhkan bantuan. ${ }^{24}$ Tuhan Yesus menggunakan metode yang berbeda-beda bergantung pada situasi, kepentingan, dan masalah yang spesifik. Dia mendengarkan orang secara teliti, mengajarkan dengan tegas dan memberikan dorongan, serta tantangan dan konfrontasi. Dia menerima orang berdosa, tetapi Ia juga menuntut pertobatan, kepatuhan, dan tindakan.

\section{KONSELING PASTORAL: SUATU PENDEKATAN PEMURIDAN}

\section{Distingsi antara Konseling Sekuler dan Konseling Pastoral}

Memang selama ini sudah terbentuk suatu persepsi bahwa konseling pastoral lebih berfungsi untuk penyembuhan, penopangan, pembimbingan, dan pendamaian. Akan tetapi konseling pastoral tidak hanya berfungsi sebagaimana disebutkan, melainkan konseling pastoral juga berfungsi untuk pemberdayaan. ${ }^{25}$ Apabila kita memperhatikan beberapa pendekatan konseling pastoral, di sana kita menemukan bahwa konseling pastoral berusaha untuk mengubah hidup menjadi lebih efektif dan bermakna.

\footnotetext{
${ }^{24}$ Gary R Collins, Christian Counseling: A Comprehensive Quide, third edition (Nashville: Thomas Nelson, 2007), p. 29.

${ }^{25}$ Totok S. Wiryasaputra, Pengantar Konseling Pastoral (Yogyakarta: Diandra Pustaka Indonesia, 2014), hal. 80.
} 
Baiklah kita membuat terlebih dahulu suatu pembedaan antara konseling sekuler dengan konseling pastoral. Pertama-tama harus diakui bahwa istilah "konseling" mula-mula tumbuh dan berkembang dari kajian ilmu psikologi. Untuk menetapkan secara pasti kapankah psikologi mulai dipelajari secara ilmiah memang terasa sulit, namun secara umum, psikologi sebagai ilmu otonom (psikologi ilmiah) dapat ditetapkan tahun 1870 sebagai acuan, ketika Prof. Wilhelm Wundt dari Universitas Leipzig Jerman mendirikan laboratorium untuk menyelidiki perilaku manusiat. ${ }^{26}$ Psikologi sebagai ilmu otonom semakin diminati oleh para ahli dan terus berkembang dengan berbagai bidang kajian seperti yang kita kenal dewasa ini. Psikologi sebagai ilmu murni, terus mengembangkan juga kajian-kajian terapan, seperti "psikologi klinis, psikologi konseling, atau psikologi sekolah. Istilah konseling baru diperkenalkan di Indonesia oleh Sri Mulyani Martaniah pada tahun 1970-an". ${ }^{27}$ Pada praktiknya, konseling dan psikoterapi menggunakan pendekatan yang sama, oleh sebab itu banyak orang berpikir bahwa konseling sama dengan psikoterapi yang berfungsi untuk menolong mereka yang mengalami gangguan mental. "Sesungguhnya konseling biasanya digunakan untuk orang normal sedangkan psikoterapi digunakan untuk menolong mereka yang mengalami gangguan mental". ${ }^{28}$ Jadi kita perlu membedakan antara konseling dan psikoterapi, antara konselor dan psikiater.

Di samping itu kita juga perlu membedakan antara konseling sekuler dan konseling pastoral. Konseling sekuler dan konseling pastoral menggunakan pendekatan yang sama, tetapi ada hal-hal yang berbeda secara prinsip. Konseling sekuler menangani masalah-masalah yang bersifat emosi, perilaku, dan pola

\footnotetext{
${ }^{26}$ Paul D. Meier, ed., Introduction to Psychology and Counseling: Christian Perspectives and Applications (Grand Rapids, Michigan: Baker Book House, 1982), p. 16. Lihat juga Jalaluddin, Kamus Ilmu Jiwa dan Pendidikan (Bandung: Alma'arif, 1977).

${ }^{27}$ Johana E. Prawitasari, Psikologi Klinis: Pengantar Terapan Mikro \& Makro (Jakarta: Erlangga, 2011), hal. 6.

${ }^{28}$ Johana E. Prawitasari, Psikologi Klinis, hal. 8.
} 
pikir/intelek. Di dalam proses konseling sekuler hanya dikenal dialog di antara konselor dengan konseli. Sementara di dalam konseling pastoral, ia menembus sampai kepada dimensi rohani. Konseling pastoral tidak semata-mata bersifat "dialogis" melainkan "trialogis" di mana dimensi iman, ke-Tuhanan dilibatkan dalam proses percakapan konseling. Di dalam proses konseling pastoral konselor selalu berusaha untuk menempatkan konseli dalam relasinya dengan Tuhan dan bertanggung jawab kepada-Nya. Konseling sekuler menangani hal-hal yang berkaitan dengan perawatan jiwa (care for the soul) sementara konseling pastoral menangani masalah-masalah yang berkaitan dengan penyembuhan jiwa (the cure of the soul), sebagaimana diungkapkan oleh Mark. R. McMinn dan Timothy R. Philips yang dikutip oleh Neil T Anderson bahwa:

Penyembuhan jiwa, jelas bukan tugas para psikolog. Para psikolog mengobati jiwa, meringankan penderitaan, menolong orang-orang yang terluka secara emosional menemukan kembali arti dan tujuan, serta mendorong orang untuk melihat diri sendiri, orang lain dan dunia secara lebih tepat. Singkatnya para psikolog melakukan perawatan jiwa. Penyembuhan jiwa..... adalah pekerjaan Allah dan berada di luar jangkauan psikologi konvensional. ${ }^{29}$

Hal lain yang membuat konseling pastoral berbeda dengan konseling sekuler ialah kata pastoral. Kata pastoral hendak mengarahkan bahwa konseling tersebut berlangsung dalam kaitan yang sangat kuat dengan fungsi gereja, khususnya dalam tugas penggembalaan. Kata pastoral juga lebih memberikan tekanan dan arah terhadap tindakan penggembalaan. Tekanan dan arah ini berkaitan dengan perhatian gembala yang berakar di dalam berita

\footnotetext{
${ }^{29}$ Neil T. Anderson, Menjadi Gereja, hal. 68-69.
} 
Injil. ${ }^{30}$ Dengan demikian maka, konseling pastoral adalah suatu proses pertolongan dalam perspektif pastoral, yang terjadi melalui percakapan dan hubungan timbal balik, sehingga mereka yang ditolong mencapai pemahaman dan pengertian yang lebih lengkap mengenai dirinya, lingkungannya, serta hubungan dan tanggung jawabnya kepada Tuhan. ${ }^{31}$

\section{Tujuan Konseling Pastoral}

Ketika kita berbicara mengenai tujuan konseling pastoral, sudah pasti banyak tujuan yang hendak dicapai melalui suatu kegiatan konseling. Supaya tidak menyebutkan semua tujuan konseling pastoral seperti yang sudah kita kenal selama ini, maka dalam tulisan ini penulis hanya akan membahas tujuan konseling pastoral dalam kaitannya dengan pemuridan. Pemuridan adalah suatu usaha sadar yang dilakukan oleh gereja secara terencana dan sistematis untuk mendewasakan setiap orang yang telah percaya kepada Tuhan Yesus. Dari ungkapan tersebut, maka tujuan pertama dan utama yang hendak dicapai ialah menolong setiap warga gereja untuk mencapai kedewasaan di dalam beberapa aspek:

\section{Kedewasaan dalam Kerohanian}

Dalam kaitan dengan konseling pastoral sebagai suatu pendekatan pemuridan, maka konselor pastoral memfasilitasi warga jemaat sebagai sesama anggota tubuh Kristus untuk terus menerus meningkatkan dan saling memberdayakan untuk mencapai kedewasaan rohani. Konselor pastotal membantu warga jemaat agar mereka dapat mencapai kemerdekaan dan kebebasan dalam Kristus sehingga mereka dapat menyembah dan melayani Tuhan

\footnotetext{
${ }^{30}$ Carroll A. Wise, Pastoral Counseling: It's Theory and Practice (New York: Harper and Brothers, 1951), p. 8.

${ }^{31}$ Marthen Nainupu, Peduli Terhadap Sesama melalui Konseling Pastoral (Malang: Media Nusa Creative, 2016), hal. 17.
} 
dengan lebih baik, seperti yang Tuhan kehendaki. ${ }^{32}$ Kedewasaan rohani sebagai tujuan konseling pastoral, berusaha untuk "membebaskan, memperkuat dan memelihara keutuhan hidup yang berpusat pada Roh". ${ }^{33}$ Konselor pastoral membantu dan mengarahkan warga jemaat untuk berjumpa dengan Kristus sebagai pusat pertumbuhan kerohanian dan bersekutu dengan Dia dalam suatu persekutuan secara pribadi. Dengan demikian maka setiap warga jemaat dimampukan mengalami kehidupan yang lebih bermakna. Kedewasaan rohani merupakan hal yang mendasar di dalam seluruh kehidupan manusia dan hampir semua masalah manusia berkaitan dengan masalah rohani. Hal mana diungkapkan oleh Carl Jung bahwa di antara pasien-pasiennya yang berumur lebih dari tiga puluh lima tahun "belum ada satu yang pada akhir masalahnya tidak menemukan pandangan agama dalam kehidupan". ${ }^{34}$

Konselor pastoral menjadi seorang pemimpin rohani yang memandu pertumbuhan rohani, membantu warga jemaat untuk membangun keberanian dalam menjalani perjuangan rohani dan memungkinkan mereka untuk menemukan keyakinan dan nilainilai yang bermakna. Konselor pastoral berusaha untuk meyakinkan warga jemaat bahwa percakapan mereka bukannya sekedar berlangsung secara "dialog" atau pembicaraan antara konselor dan konseli, melainkan suatu percakapan yang berlangsung secara "trialogue" yaitu mengakui kehadiran Allah sebagai Pribadi ketiga yang hadir dalam percakapan itu dan oleh Dia perubahan itu dapat berlangsung secara efektif. Konselor pastoral membantu manusia untuk sadar akan perlunya kebutuhan

\footnotetext{
${ }^{32}$ Larry Crabb, Konseling Kristen yang Efektif dan Alkitabiah (Yogyakarta: Yayasan Andi, 1995), hal. 17.

${ }^{33}$ Howard Clinebell, Tipe-Tipe Dasar Pendampingan dan Konseling Pastoral (Yogyakarta: Kanisius, 2002), hal. 33.

${ }^{34}$ Gary R Collins, Christian Counseling: A Comprehensive Quide, third edition (Nashville: Thomas Nelson, 2007), p. 66.
} 
rohani yang membawa keutuhan rohani pula sebagai dasar dari konseling pastoral.

Secara teknis saling membantu dan saling memberdayakan dilakukan melalui suatu proses pengubahan tingkah laku. Pengubahan tingkah laku adalah suatu proses untuk menghapus perilaku-perilaku yang buruk dan merusak. Pengubahan perilaku buruk dan membangun perilaku konstruktif adalah suatu pola pemuridan sejati. Dalam bahasa Rasul Paulus ia mengatakan, "Karena itu matikanlah dalam dirimu segala sesuatu yang duniawi, yaitu percabulan, kenajisan, hawa nafsu, nafsu jahat, dan juga keserakahan, yang sama dengan penyembahan berhala" (Kolose 3:5). Jadi konseling pastoral sebagai suatu pendekatan pemuridan mempunyai tanggung jawab untuk membebaskan warga jemaat dari berbagai hambatan pertumbuhan kerohanian untuk mencapai kedewasaan rohani. Pengubahan perilaku adalah suatu usaha konseling pastoral untuk membongkar manusia lama dan membangun manusia baru dalam Kristus. Mengembangkan perilaku, perasaan, sikap, dan nilai konstruktif merupakan hal yang utama dari keseluruhan proses konseling pastoral. Dengan kata lain pengubahan perilaku dari yang buruk kepada perilaku yang baik adalah suatu proses belajar ulang. ${ }^{35}$ Konseling pastoral sebagai suatu pendekatan pemuridan memiliki tujuan untuk mengubahkan hidup, membawa warga jemaat untuk menjadi dewasa dalam iman kepada Tuhan Yesus, memiliki rasa tanggung jawab terhadap gereja, dan berperan aktif dalam pelayanan gereja.

\section{Kedewasaan dalam Aspek Sosial}

Dalam kaitan dengan konseling pastoral sebagai suatu pendekatan pemuridan, maka konselor pastoral memfasilitasi

\footnotetext{
${ }^{35}$ John C. Hoffman, Permasalahan Etis dalam Konseling (Yogyakarta: Kanisius, 1993), hal. 60 .
} 
warga jemaat sebagai sesama anggota tubuh Kristus untuk mampu hidup dengan dirinya sendiri dan dengan sesamanya dalam persaudaraan dan cinta kasih yang ikhlas dan jujur. Konselor pastoral memberdayakan warga jemaat sehingga mereka mampu bertindak benar sesuai dengan iman dan keyakinan mereka dan bukannya bertindak dalam keragu-raguan dan kecemasan. Konselor pastoral menolong warga jemaat sehingga mereka mampu menghadirkan kedamaian di sekitar kehidupan mereka. ${ }^{36}$ Tujuan sebagaimana dijelaskan di atas hanya dapat dicapai dengan lebih baik melalui pendekatan konseling pastoral. Di dalam atau melalui khotbah, seminar, dan katekisasi misalnya itu semuanya baik, dan telah membuat gereja tetap ada sampai saat ini. Tetapi harus diakui bahwa kegiatan-kegiatan tersebut hanya berbicara secara umum, pada tataran normatif dan hanya menyentuh aspek kognitif. Sedikit berbeda dengan konseling pastoral yang melakukan percakapanpercakapan yang mendalam untuk membantu warga jemaat mengalami pengalaman dan perasaan-perasaannya secara utuh. Konselor pastoral mendampingi warga jemaat untuk dapat membedakan perasaannya secara tepat (self critical). Mampu menguasai perasaan-perasaannya yang sedang berkecamuk di dalam hatinya. Tidak mudah emosi atau fanatik terhadap agamanya bila agamanya dilecehkan oleh orang lain. Ia tetap memegang teguh agamanya dan melayani orang-orang di dalam gerejanya. Respek secara obyektif terhadap sesama, tidak pilih orang atau status sosial ekonomi dalam membangun persahabatan, utuh dalam loyalitas terhadap sesama, tidak setengah-setengah dalam hal menolong. Ini semua adalah karakteristik dari manusia yang dewasa dari aspek sosialnya.

\footnotetext{
${ }^{36}$ Seward Hiltner, Pastoral Counseling (Nashville: Abingdon Press, 1949), p. 19.
} 


\section{Kedewasaan dalam Aspek Intelektual}

Dalam kaitan dengan konseling pastoral sebagai suatu pendekatan pemuridan, maka konselor pastoral memfasilitasi warga jemaat sebagai sesama anggota tubuh Kristus untuk membangun dan mengembangkan kesadaran kritis. Tidak jarang kita mendengar para pengkhotbah menyindir jemaat sebagai mereka yang pasif, belum terlibat secara baik dan aktif di dalam pelayanan. Pokoknya saya percaya Tuhan Yesus, selamat dan rajin ke gereja sudah cukup. Sindiran-sindiran semacam ini adalah suatu gaya atau cara membangkitkan kesadaran. Sebab memang masih terlalu banyak warga jemaat yang tingkat kesadarannya baru sampai pada taraf kesadaran intransitif, yaitu hanya memikirkan diri sendiri, buta terhadap hal-hal di luar dirinya. ${ }^{37}$ Akan tetapi hanya dengan sindiran demikian sekali lagi hanya bersifat umum, semacam ajakan dan himbauan saja. Sadar akan hal ini maka konseling pastoral hadir sebagai satu sayap dari pelayanan pastoral dapat menyumbangkan sesuatu bagi kebangkitan kesadaran tanggung jawab beriman. Kesadaran dapat tercapai ketika seseorang mau belajar secara terencana dan konsisten. Belajar untuk menggali dan mengembangkan sumber-sumber kekayaan diri yang sangat besar dengan pengembangan sikap kesadaran kritis melalui konseling pastoral. Kesadaran kritis merupakan kesadaran tertinggi di mana warga jemaat belajar menafsirkan masalahmasalah, peka dan tidak lari dari tanggung jawab, dapat dibangun melalui percakapan konseling pastoral. ${ }^{38}$

\footnotetext{
${ }^{37}$ Christiaan Soetopo, "Konsientisasi: Proses Pembangkitan Kesadaran” dalam Tjaard Hommes dan E. Gerrit Singgih, Teologi dan Praksis Pastoral (Yogyakarta: Kanisius, 1992), hal. 245.

${ }^{38}$ Christian Soetopo, "Konsientisasi, hal. 246.
} 


\section{Dewasa dalam Aspek Emosi}

Mengapa konseling pastoral sebagai suatu pendekatan pemuridan diperlukan? Harus diakui bahwa percaya kepada Tuhan Yesus, tidak secara otomatis seseorang menjadi dewasa. Pengalaman penulis selama beberapa tahun sebagai pendeta jemaat, penulis melihat sendiri bahwa masih terlalu banyak endapanendapan emosi negatif, buruk seperti kebencian, dendam dan amarah, dan lain-lain yang belum terselesaikan, meskipun sudah lama menjadi orang Kristen. Pengalaman semacam itu barangkali merupakan suatu pengalaman umum di dalam kehidupan bergereja. Masih ada warga jemaat yang hidup dalam kekanak-kanakkan atau bayi rohani, tergantung pada dorongan-dorongan nawa nafsu (id), dan kehausan psikologis yang barangkali telah terstruktur di dalam dirinya, ada kecenderungan untuk memanfaatkan tema-tema agama seperti melayani untuk kepuasan hasrat psikologisnya. Melalui konseling pastoral warga jemaat ditolong untuk membangun motivasi yang kuat dalam dirinya, sebab hal tersebut merupakan kunci kedewasaan rohani yang teraktualisasi dalam trasformasi kehidupan. Melalui konseling pastoral warga jemaat ditolong untuk konsisten dalam konsekuensi moral. Ia tidak mengorbankan nilainilai moral hanya untuk mencari popularitas sementara. Keaslian dari dinamika hidup imannya selalu teruji dalam tindakannya di luar gedung gereja. Berkaitan dengan konsistensi adalah pandangan hidup. Ia memiliki pandangan dan teologi yang kuat dan jelas, tidak gado-gado dan campur aduk semua pandangan. Kata dan iman menjadi satu dalam aksi dan praksis. Selalu mencari dan mengejar kesalehan dan kesucian hidup (Filipi 3:12). Melalui konseling pastoral warga jemaat dimampukan untuk mengenal dan berani mengambil langkah perubahan dalam pusat emosional dari egosentris kepada cinta kasih yang tulus terhadap sesamanya dan membangun hubungan yang harmonis dengan sesamanya. Warga jemaat dimampukan untuk membangun perasaan dan keyakinan 
bahwa ia hidup dan tinggal dalam dunia yang sangat luas dan tidak terkurung di dalam keinginannya yang sempit dan dangkal.

\section{Makna Konseling Pastoral sebagai Pendekatan Pemuridan}

\section{Membangkitkan Kesadaran Kritis terhadap Dosa}

Mengapa gereja sedang bangkit dengan semangat untuk melakukan pemuridan? Tentu banyak alasan dan pertimbangan, tetapi barangkali salah satu alasan yang kuat ialah bahwa selama ini gereja telah terlena dan tertidur dengan kegiatan-kegiatan rutin di dalam gereja. Persoalan bagi gereja sekarang ialah bukan soal mengetahui kebenaran, melainkan soal mewujudkan kebenaran itu dalam aksi-aksi nyata. Gereja sudah terlalu banyak berbicara tentang kebenaran, namun masih terlalu miskin untuk memunculkan kebenaran itu dalam tindak. Visi misi hanya sekedar slogan atau wacana, tetapi tidak pernah mewujud dalam aksi nyata. Barangkali gereja suka pakai "topeng" seperti halnya kemunafikan para Farisi. Mereka masih banyak memiliki sifat yang baik hingga membentuk suatu kepribadian yang baik, yang tampaknya tak ada hal yang tercela di dalamnya, akan tetapi mereka tidak luput dari kritikan dan kecaman Tuhan Yesus (Matius 23), berpura-pura melakukan suatu kegiatan rohani (keagamaan) tertentu secara bersemangat dengan maksud mengelabui orang lain, sering kali secara terus menerus sibuk dengan berbagai kegiatan rohani tanpa hentinya, sangat dogmatis dan tidak jarang menggunakan ayat-ayat kitab Alkitab yang "cocok" untuk mempertahankan dan membenarkan diri, tidak segan-segan pula ia menggunakan "nama Tuhan" demi pembenaran kejahatannya. Mengapa para Farisi dan ahli Taurat dikecam oleh Tuhan Yesus? Bukankah mereka adalah orang-orang yang sangat setia memelihara hukum Taurat dan selalu hadir dan duduk di bagian terdepan di dalam kegiatan-kegiatan Bait Allah? Adalah sangat berbahaya apabila gereja telah kehilangan 
kepekaan dan ketazaman untuk melihat bahwa kemunafikan seperti adalah suatu kejahatan.

Pemuridan melalui konseling pastoral dapat menolong warga jemaat untuk menyadari akan bahaya-bahaya yang melumpuhkan kekuatan dan mematikan pertumbuhan kerohanian. Sebab yang memisahkan manusia dengan Allah ialah dosa manusia. "Tetapi yang merupakan pemisah antara kamu dan Allahmu ialah segala kejahatanmu, dan yang membuat Dia menyembunyikan diri terhadap kamu, sehingga Ia tidak mendengar, ialah segala dosamu" (Yesaya 59:2). Kegiatan yang berlangsung secara formal terkadang hanya menyenangkan secara budaya tetapi menyembunyikan banyak kejahatan di dalamnya. Banyak orang yang menghadiri kebaktian hari Minggu, berusaha menampilkan sikap sopan, ramah, dan kasih satu terhadap yang lain. Sikap-sikap semacam itu sangat diterima secara budaya, tetapi apakah di dalam ruang kebaktian itu tidak ada sikap-sikap yang tersembunyi seperti kebencian, iri hati, permusuhan di antara mereka yang hadir dalam kebaktian itu? Kalau dijawab secara jujur ya pasti ada. Sebab kebaktian dalam bentuk formalitas, ritual, legalisme, cenderung mereduksi iman sejati dan menggantikan iman kepura-puraan dan kesombongan religius.

Pemuridan melalui konseling pastoral dapat membangkitkan kesadaran kritis terhadap perilaku-perilaku yang merusak, perilaku formalitas, ritual, legalisme. Sesuai dengan ke-khasannya konseling pastoral melibatkan diri dalam percakapan yang mendalam dan luas mengenai persoalan-persoalan kehidupan manusia. Dengan cara itu konselor pastoral dapat menolong warga jemaat untuk bersikap kritis dan mawas diri terhadap berbagai dosa dan kejahatan yang tidak disadarinya. Di ruang-ruang konseling pastoral di sana banyak orang mengaku dengan jujur akan berbagai dosa dan kejahatan yang tertutup rapat selama ini. Melalui percakapan 
konseling pastoral, sangat memungkinkan dapat membangkitkan dan menumbuhkan kesadaran kritis terhadap dosa.

\section{Mewujudkan Perubahan dan Pertumbuhan Jemaat Secara Utuh}

Pada dasarnya konseling pastoral berarti menolong seluruh warga jemaat untuk mengalami perubahan dan pertumbuhan di dalam semua dimensi dirinya, membantu warga jemaat untuk dapat mengembangkan dan mengaktualisasikan semua potensi dirinya secara utuh dan penuh. Utuh berarti semua bagian dari kehidupannya terbangun dan penuh berarti semua bagian tadi secara bersama-sama dapat mencapai suatu titik secara sempurna, lengkap, tidak ada yang tersisa atau tertinggal. Konseling pastoral sebagai usaha untuk menolong warga jemaat mengalami perubahan dan pertumbuhan adalah merupakan suatu proses perkembangan yang berlangsung dalam suatu relasi yang bermakna di antara konselor pastoral dan warga jemaat. Maka di sini konselor pastoral harus sadar diri agar dia tidak memanipulasi pihak lain dalam hal ini warga jemaat untuk memenuhi kebutuhan dan keinginannya sendiri. Konselor pastoral tidak sekedar simpati, tidak sekedar untuk peduli dengan orang lain, melainkan ia harus menghadirkan dirinya sebagaimana Kristus telah hadir bagi dirinya.

Relasi yang bermakna seperti inilah sebagai suatu kondisi yang sangat dibutuhkan agar tercipta perubahan dan pertumbuhan. Kehadiran konselor pastoral merupakan representasi kehadiran Tuhan Yesus bagi jemaat. Tuhan Yesus sebagai model konselor pastoral, ketika Ia bersama dengan para murid-Nya, Ia hadir secara otentik, tidak memanipulasi, dan tidak sekedar menunjukan sikap belas kasihan. Ia tampil dengan seluruh dirinya demi perubahan dan pertumbuhan para murid. Kehadiran konselor pastoral yang mengambil pola kehadiran Tuhan Yesus, hal itulah yang akan 
memungkinkan terjadinya perubahan dan pertumbuhan bagi warga jemaat yang sedang didampingi.

\section{Meneruskan Karya Pemuridan Tuhan Yesus}

Ketika Tuhan Yesus akan meninggalkan para murid-Nya, Ia berpesan kepada mereka, "Karena itu pergilah, jadikanlah semua bangsa murid-Ku..." (Matius 28:19). Sebelum Tuhan Yesus berpesan seperti itu, Ia sendiri telah melakukan tugas pemuridan tersebut. Ia telah membangun suatu komunitas murid sebagai persiapan generasi penerus dari semangat pemuridan. Manusia sebagai ciptaan Allah yang pada awalnya hidup dalam damai sejahtera dan persekutuan dengan Tuhan, namun dosa telah memisahkan manusia dari Tuhan, ia terputus dari persekutuan dengan Bapa. Meskipun demikian, di dalam dan oleh Kristus manusia dapat didamaikan dan dipersekutukan kembali dengan Allah. Tuhan Yesus menghendaki agar keselamatan manusia yang sudah diberikan oleh-Nya dapat dimiliki semua manusia secara utuh dan untuk itu usaha pemuridan dapat menjadi suatu strategi untuk mewujudkan keselamatan bagi segala bangsa. Sebab hanya melalui proses pemuridan, di sanalah manusia akan memperoleh pencerahan, pemahaman, pengertian, dan pengetahuan yang benar mengenai arti melayani, bersaksi, dan keselamatan dan dari situ pula lahirlah iman yang menghantar kepada keselamatan dan kehidupan kekal.

Konseling pastoral sebagai salah satu bagian dari keseluruhan pelayanan penggembalaan sangat membantu untuk menolong warga jemaat berpartisipasi aktif dalam meneruskan tugas pemuridan seperti yang diamanatkan oleh Tuhan Yesus. Pemuridan melalui konseling pastoral merupakan suatu strategi gereja untuk meneruskan dan mewujudkan tugas pemuridan. Tugas pemuridan tidak akan pernah berhenti, kecuali apabila tugas tersebut telah 
mencapai titik terakhir seperti yang digambarkan dalam kitab wahyu. "Lalu aku melihat langit yang baru dan bumi yang baru, sebab langit yang pertama dan bumi yang pertama telah berlalu, dan lautpun tidak ada lagi. Dan aku melihat kota yang kudus, Yerusalem yang baru, turun dari sorga, dari Allah, yang berhias bagaikan pengantin perempuan yang berdandan untuk suaminya. Lalu aku mendengar suara yang nyaring dari takhta itu berkata: "Lihatlah, kemah Allah ada di tengah-tengah manusia dan Ia akan diam bersama-sama dengan mereka. Mereka akan menjadi umatNya dan Ia akan menjadi Allah mereka. Dan Ia akan menghapus segala air mata dari mata mereka, dan maut tidak akan ada lagi; tidak akan ada lagi perkabungan, atau ratap tangis, atau dukacita, sebab segala sesuatu yang lama itu telah berlalu" (Wahyu 21:1-4). Gereja dan seluruh warganya sebagai umat pilihan Tuhan, hendaknya memiliki kerinduan dan komitmen untuk meneruskan dan melibatkan diri secara aktif dalam tugas pemuridan agar semua bangsa menjadi murid Tuhan Yesus, bagi kemuliaan Allah bapa.

\section{PENUTUP DAN KESIMPULAN}

Pemuridan merupakan suatu strategi pendewasaan warga jemaat dan penyebar luasan nilai-nilai kerajaan Allah di tengah kehidupan gereja dan dunia. Untuk mencapai maksud tersebut, gereja telah mengembangkan berbagai cara untuk melakukan tugas pemuridan. Salah satu cara dalam pemuridan yang tertuang dalam tulisan ini ialah konseling pastoral atau yang Anderson menyebutnya dengan sebutan "konseling pemuridan". 39 Konseling pastoral sebagai suatu pendekatan pemuridan dibangun dari pola pemuridan Tuhan Yesus. Pola pemuridan Tuhan Yesus berawal dari panggilan menjadi murid, proses menjadi murid dan yang pada akhirnya dapat memuridkan orang lain sesuai dengan amanat Tuhan Yesus. Konseling pastoral dengan ke-khasannya melakukan

\footnotetext{
${ }^{39}$ Neil T. Anderson, Menjadi Gereja, h. 67.
} 
percakapan yang mendalam dan luas mengenai berbagai aspek kehidupan, maka dengan cara tersebut sangat berguna untuk memungkinkan dan menyadarkan warga jemaat akan pentingnya pertumbuhan dan kedewasaan kerohanian orang percaya.

Konseling pastoral sebagai suatu pendekatan pemuridan sangat memungkinkan warga jemaat dapat tumbuh secara rohani mengingat tujuan yang mau dicapai melalui konseling pastoral ialah membebaskan, memulihkan, memperkuat, dan memelihara keutuhan hidup yang berpusat pada Kristus dan Firman-Nya. Selain itu melalui konseling pastoral warga jemaat dimampukan untuk hidup dengan dirinya sendiri dan dengan sesamanya dalam persaudaraan dan cinta kasih yang ikhlas dan jujur serta menghadirkan kedamaian di sekitar kehidupan mereka. Melalui konseling pastoral warga jemaat ditolong untuk membangun motivasi yang kuat dalam dirinya, sebab hal tersebut merupakan kunci kedewasaan rohani yang teraktualisasi dalam transformasi kehidupan. Melalui konseling pastoral warga jemaat ditolong untuk konsisten dalam konsekuensi moral. Ia tidak mengorbankan nilainilai moral hanya untuk mencari popularitas sementara. Apabila semuanya itu dapat terwujud dengan baik, maka di sanalah boleh dikatakan bahwa tugas pemuridan telah berjalan dengan baik dan yang lebih penting lagi ialah bahwa semua warga jemaat dapat ikut serta secara aktif dalam memuridkan orang lain.

\section{DAFTAR RUJUKAN}

Adisubrata, K. Prent CM, J. dan W. J. S. Porwadarminta. Kamus Bahasa Latin-Indonesia. Yogyakarta: Kanisius 1969.

Armstrong, Ann. Listening for the Healing Word. Grandview-USA: Desert Stream Press, 2009. 
Berneir, Paul. Ministry in the Church: A Historical and pastoral Approach .Mystic, Connecticut: Twenty-Third Publications, 1992.

Bruce, A. B. The Training of the Twelve. Grand Rapids, Michigan: Kregel Publications, 1971.

Buttrick, George A. The Interpreter's Doctionary of the Bible, $R-$ Z, vol. 4.Nashville: Abingdon Press, 1962.

Clinebell, Howard. Tipe-Tipe Dasar Pendampingan dan Konseling Pastoral. Yogyakarta: Kanisius, 2002.

Collins, Gary R. Christian Counseling: A Comprehensive Quide, third edition. Nashville: Thomas Nelson, 2007.

Crabb, Larry. Konseling Kristen yang Efektif dan Alkitabiah. Yogyakarta: Yayasan Andi, 1995.

Elwell, Walter A. Baker Theological Dictionary of Bible. Michigan: Baker Book's, 1996.

France, R. T. Matthew Evangelist and Teacher. Grand Rapids, Michigan: Zondervan Publishing House, 1989.

Hiltner, Seward. Pastoral Counseling. Nashville: Abongdon Press, 1949.

Hoffman, John C. Permasalahan Etis dalam Konseling. Yogyakarta: Kanisius, 1993.

Hommes, Tjaard dan E. Gerrit Singgih. Teologi dan Praksis Pastoral.Yogyakarta: Kanisius, 1992. 
Hull, Bill. Jesus Christ, Disciplemaker. Surabaya: Literatur Perkantas Jawa Timur, 2015.

Jalaluddin. Kamus Ilmu Jiwa dan Pendidikan. Bandung: Alma'arif, 1977.

Meier, Paul D. ed. Introduction to Psychology and Counseling: Christian Perspectives and Applications. Grand Rapids, Michigan: Baker Book House, 1982.

Nainupu, Marthen. Peduli Terhadap Sesama Melalui Konseling Pastoral. Malang: Media Nusa Creative, 2016.

Ogilvie, Lloyd. J. gen. ed. The Communicator's Commentary: Matthew. Waco-Texas: Word Books, Publisher, 1982.

Platt, David. Mengikut Yesus Tak Peduli Berapapun Harganya. Surabaya: Literatus Perkantas Jawa Timur, 2016.

Poerwadarminta, W. S. J. Kamus Umum Bahasa Indonesia. Jakarta: Balai Pustaka, 1984.

Prawitasari, Johana E. Psikologi Klinis: Pengantar Terapan Mikro \& Makro. Jakarta: Erlangga, 2011.

Price, J. M. Yesus Guru Agung. Bandung: LLB, tanpa tahun. Wiryasaputra, Totok S. Pengantar Konseling Pastoral. Yogyakarta: Diandra Pustaka Indonesia, 2014.

Wise, Carroll A. Pastoral Counseling: It's Theory and Practice. New York: Harper and Brothers, 1951. 
140 Pemuridan Melalui Pendekatan Konseling Pastoral

Wright, H. Norman. Konseling Krisis, Membangun Orang Dalam Krisis dan Stres. Malang: Gandum Mas, 1993.

Yount, William R. \& Mike Barnett. Called To Reach. Nashville, Tennessee, B \& H Publishing Group, 2007. 